\title{
Weathering characteristics of the Lower Paleozoic black shale in northwestern Guizhou Province, south China
}

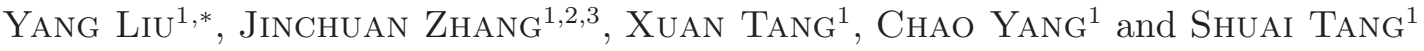 \\ ${ }^{1}$ School of Energy Resources, China University of Geosciences, Beijing 100083, China. \\ ${ }^{2}$ Key Laboratory of Shale Gas Exploration and Evaluation, Ministry of Land and Resources, \\ China University of Geosciences, Beijing 100083, China. \\ ${ }^{3}$ Key Laboratory of Marine Reservoir Evolution and Hydrocarbon Abundance Mechanism, Ministry of Education, \\ China University of Geosciences, Beijing 100083, China. \\ ${ }^{*}$ Corresponding author.e-mail: ly7531@163.com
}

The northwestern Guizhou in the Yangtze Craton of south China has a tremendous potential of shale gas resource. In this paper, we present results from major and trace elements, total organic carbon, mineralogical composition analysis and petrophysical parameters to characterise shale weathering features. Further, the differences of black shale between underground and outcrops have also been presented to examine the changes of black shale after weathering. Our results show that the trace elements of shale have varying degrees of loss in the weathering leaching process, both in Niutitang shale and Longmaxi shale, the loss of $\mathrm{B}, \mathrm{V}, \mathrm{Ni}, \mathrm{Cu}, \mathrm{Zn}$ and $\mathrm{Ba}$ is obvious, but the element migration quantity in the former is greater than in the latter. Decomposition of minerals such as pyrite, feldspar and calcite result in the leaching of $\mathrm{Na}, \mathrm{Ca}, \mathrm{Mg}$ and $\mathrm{Fe}$. The loss rate of total organic carbon (TOC) in black shales ranges from $18 \%$ to $70 \%$ with an average of $43 \%$; moreover, the loss of organic carbon in samples with high TOC content is larger than in those samples with low TOC content. Results following the testing of porosity and permeability show that porosity increases significantly after weathering but permeability changes little. Furthermore, the increment of porosity is greater in the Niutitang shale (with more sulphide minerals) than in the Longmaxi shale, suggesting that the oxidation of sulphide minerals may have led to the formation of an acidic environment, causing the other minerals in the black shale to weather more quickly, thus resulting in increased porosity. The content of clay minerals in the core samples is slightly lesser than the outcrop samples, but the TOC content in the core samples is greater and has a larger specific surface area. This suggest that the TOC content played a decisive role on the specific surface area of shale. In addition, changes in the black shale caused by the weathering process mainly depend on the mineral composition and the TOC content in shale. In this study, we try to establish relations between outcrop samples and core samples, in order to better understand the underground characteristics of shale reservoir.

\section{Introduction}

Shale gas refers to natural gas that typically accumulates in an adsorbed or unbound state, which is mainly found in black shale or carbonaceous shale
(Curtis 2002; Chen et al. 2003; Zhang et al. 2003, 2004, 2007; Li et al. 2007). The shale gas in North America is developing very rapidly with the breakthrough of horizontal wells and the staged fracturing technology (Huang et al. 2009), so the strategic

Keywords. Weathering; black shale; northwestern Guizhou; shale gas; south China. 
position of shale gas resources is paid great attention gradually. Shale gas also has good development prospects in China and the resource is about twice as many the continental conventional natural gas resources (Yan et al. 2009; Zou et al. 2010). The marine facies, Paleozoic black shale, in Yangtze Craton has good hydrocarbon generation and shale gas reservoir conditions, which is the most famous shale gas production area in China, at present. The Niutitang shale in the Lower Cambrian and the Longmaxi shale in the Lower Silurian, on the other hand, have the most enriched shale gas formation (Jia et al. 2012). Geologic reserves of shale gas in the Guizhou province is $10.48 \times 10^{12} \mathrm{~m}^{3}$ and account for $12.8 \%$ for the whole China, which has a tremendous potential as shale gas resource (Wu et al. 2012).

Black shales, with a wide global distribution, were often deposited in relatively deep, anoxic ocean basins (Horan et al. 1994; Tuttle and Breit 2009), where sediments accumulated, often times, very slowly. As such, black shales usually have a high content of organic carbon and sulphides and are important hosts for a remarkable array of ore metals such as Co, Ni, V, U, Mo, Mn, P, and the PGE (platinum group elements) (Horan et al. 1994; Mao et al. 2002; Jiang et al. 2006). Because of their high organic carbon and sulphide contents, black shales are susceptible to alteration when exposed, and thus mining in shales throughout the world has accelerated the weathering of these sedimentary rocks. The weathering of black shale is an important environmental concern because of the dispersion of toxic metals hosted by the shales, the production of acid mine drainage - which can harm the ecosystem due to oxidation of sulphides (Peng et al. 2004, 2009a), and the release of $\mathrm{CO}_{2}$, which may contribute to the global carbon cycle (Petsch et al. 2000, 2001; Jaffe et al. 2002). Oxidative weathering of black shales produces $\mathrm{CO}_{2}$ and releases many redoxsensitive trace elements (RST) U, Re and Mo into rivers. Therefore, this process contributes significantly to atmospheric $\mathrm{CO}_{2}$ budgets in geological time scale as well as RST and their isotope budgets in the oceans, as some of them are used as paleooceanographic proxies (Dalai et al. 2002; Jaffe et al. 2002). The weathering of black shale has therefore received substantial research attention, especially the chemical changes during weathering (Littke et al. 1991; Jaffe et al. 2002; Tuttle and Breit 2009; Tuttle et al. 2009). Such chemical changes are generally explained by mineral dissolution, secondary mineral formation, cation exchange and loss and gain of amorphous oxide phases (Tuttle and Breit 2009).

Most of the weathering process includes physical and chemical weathering, but physical weathering often occurs only near the surface while chemical weathering can extend to the range of hundreds

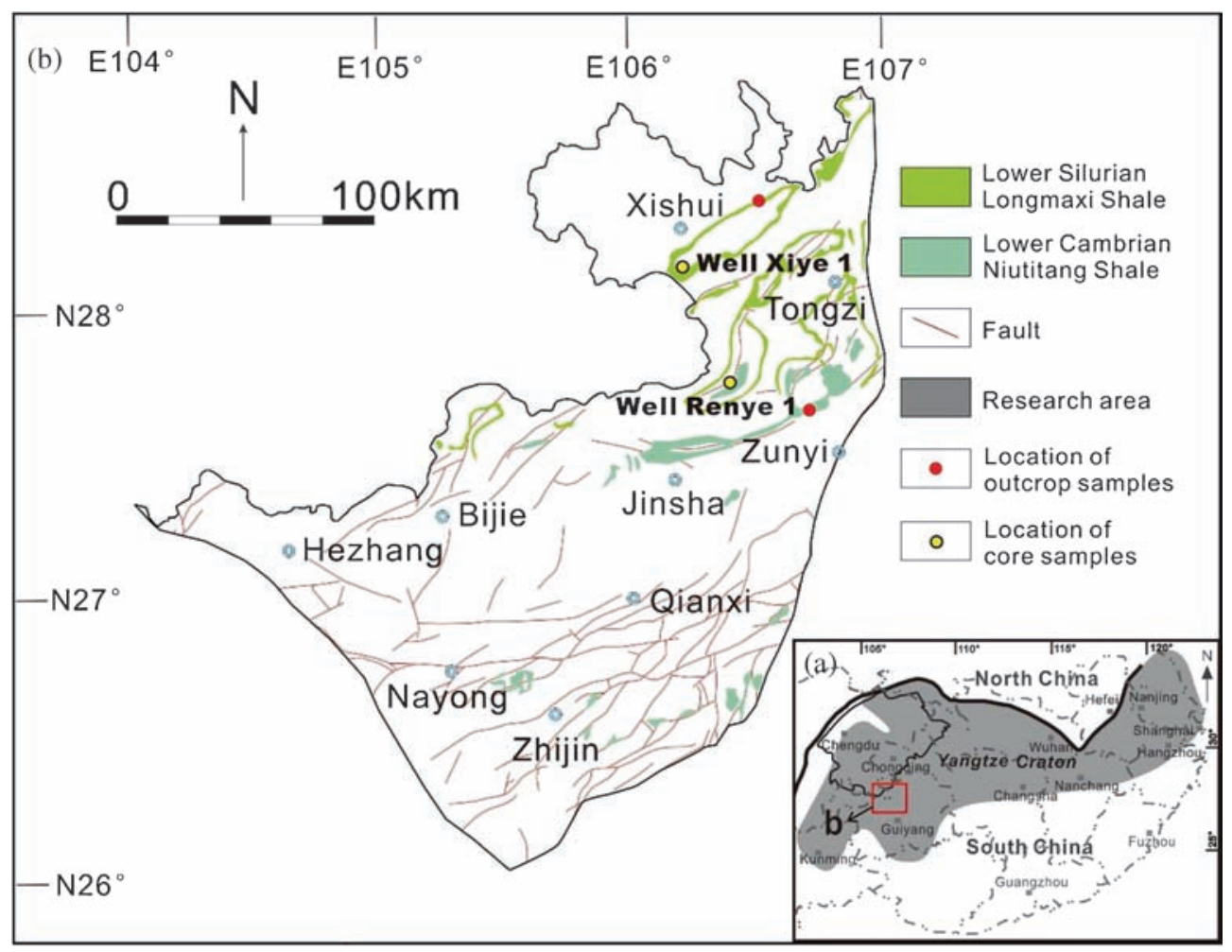

Figure 1. (a) The location of the northwestern Guizhou area within the Yangtze Craton. (b) Geological sketch map of the northwestern Guizhou Province. 
of meters below the surface (Chorley 1969). Black shales have become the focus of many weathering studies because they contain phases such as sulphides and organic matter that host elements of environmental concern (Petsch et al.2000; Jaffe et al. 2002; Peng et al. 2004, 2009). During weathering, these phases are easily altered, releasing contaminants into the environment where they are transported from the site or fixed in secondary weathering products. Semi-arid and arid climates play a key role in the accumulation of soluble weathering phases, providing large reservoirs of easily mobilised contaminants to watersheds and their rivers when hydrologic or climatic conditions change. However, the weathering of black shale, as the shale gas reservoir, has not been reported as yet and a comparison of the black shale between outcrops and underground has also not been tried.

In this paper, we present the geochemistry, mineralogical composition and petrophysical parameters data of black shale to understand the significant change on its organic and inorganic features such as lithological and mineral composition after weathering. We also attempt to evaluate the distinction and establish the relationship between the black shale from underground and those from outcrops. This is conducive to restore the original features of the strata from outcrop data, thereby guiding the exploration of shale gas.

\section{Regional geological setting}

The Guizhou province is located at the southwestern margin of the Yangtze Craton. This area is covered by the strata from Mesoproterozoic and Neoproterozoic to Quaternary, which is mainly marine sedimentary. Sedimentary strata of middle to Upper Proterozoic are dominated by marine terrigenous clastic rocks, pyroclastic rock and carbonatite, Paleozoic to Middle-Upper Triassic are mainly composed of marine carbonate and clastic rocks, Middle Triassic are mainly terrigenous clastic rocks (figure 1) (Fu et al. 2008; Liu et al. 2008; Zhang et al. 2009; Dong et al. 2009; Huang 2009; Nie et al. 2011).

Northwestern Guizhouis mostly located in Guizhou uplift zone which is one of the east-west uplift belts in Yangtze Craton is formed in the early Paleozoic. The exposed stratigraphic sequence in this area mainly consists of Cambrian, Ordovician, Silurian, Carboniferous, Permian, Triassic, Jurassic, and Quaternary units. During Cambrian to Middle Silurian time, the region experienced a large transgression-regression cycle influenced by the initial stage of Caledonian movement. This transgression-regression cycle resulted in the deposition of Cambrian to Silurian strata in this area
(Guizhou Provincial Geological Survey Bureau 1987). Because of NNE-directed compression in this region, NNE-trending anticlines, synclines and faults are ubiquitous. The black shales, usually cut by faults and fractures, are strictly controlled by anticlines and synclines (figure 2). The oldest rock in the area is the Upper Sinian of the Doushantuo Formation. The Ordovician consists of dolomite, limestone and argillite and is overlain by the lowerMiddle Silurian, which is composed of black or greyish green shales with intercalated sandstones and siltstones. During Upper Silurian to Upper Carboniferous time, a drop in the sea level led to an epeirogenic phase that exposed the Silurian to intense weathering (Guizhou Provincial Geological Survey Bureau 1987). There are no outcrops of Upper Silurian, Devonian or Lower to

\begin{tabular}{|c|c|c|c|}
\hline$\sum_{0}^{\frac{E}{0}}$ & 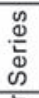 & Group & Lithology \\
\hline \multirow{2}{*}{$\begin{array}{l}\frac{\mathrm{C}}{\mathrm{E}} \\
\frac{\mathrm{E}}{0} \\
0\end{array}$} & 음 & $\left(P_{2}\right)$ & $\begin{array}{c}\text { Limestone } \\
\text { Shale }\end{array}$ \\
\hline & ฏ) & $\left(P_{1}\right)$ & Limestone \\
\hline \multirow{3}{*}{ 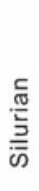 } & $\frac{0}{\frac{0}{0}}$ & $\left(\mathrm{~S}_{2}\right)$ & $\begin{array}{c}\text { Shale } \\
\text { Limestone }\end{array}$ \\
\hline & \multirow{2}{*}{ ฏ’ } & Shiniulan(S 1 sn) & Limestone \\
\hline & & Longmaxi( $\left.\mathrm{S}_{1} \mid \mathrm{m}\right)$ & Shale \\
\hline \multirow{3}{*}{$\begin{array}{l}\frac{\frac{1}{0}}{0} \\
\frac{0}{3} \\
\frac{0}{0} \\
0\end{array}$} & $\begin{array}{l}\text { ळ. } \\
\text { 음 }\end{array}$ & $\left(\mathrm{O}_{3}\right)$ & $\begin{array}{c}\text { Shale } \\
\text { Limestone }\end{array}$ \\
\hline & $\frac{\emptyset}{\frac{0}{0}}$ & $\left(\mathrm{O}_{2}\right)$ & Limestone \\
\hline & 㐫 & $\left(\mathrm{O}_{1}\right)$ & $\begin{array}{l}\text { Siltstone } \\
\text { Limestone }\end{array}$ \\
\hline \multirow{6}{*}{ 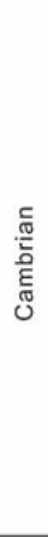 } & $\begin{array}{l}\text { ळ } \\
\text { 음 }\end{array}$ & $\left(\in_{3}\right)$ & Limestone \\
\hline & $\frac{0}{\frac{0}{0}}$ & Gaotai $\left(\in_{2 g}\right)$ & Dolomite \\
\hline & \multirow{4}{*}{ 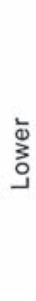 } & Qingxudong $\left(\in_{1} q\right)$ & Limestone \\
\hline & & Jindingshan $\left(\in_{1 \mathrm{j}}\right)$ & Siltstone \\
\hline & & Mingxinsi $\left(\in_{1 \mathrm{~m}}\right)$ & Silty Shale \\
\hline & & Niutitang $\left(\in_{1 \mathrm{n}}\right)$ & Shale \\
\hline \multirow{2}{*}{$\frac{c}{\frac{c}{c}}$} & \multirow{2}{*}{$\begin{array}{l}\text { ㅎ } \\
\text { 응 }\end{array}$} & Dengying(Zødn) & Dolomite \\
\hline & & Doushantuo(Zød) & Shale \\
\hline
\end{tabular}

Figure 2. Lithological and stratigraphic system of northwestern Guizhou area. 
Table 1. Major and trace elements of the black shale in northwestern Guizhou area.

\begin{tabular}{|c|c|c|c|c|c|c|c|c|c|c|c|c|c|c|c|c|c|c|c|}
\hline \multirow{2}{*}{$\begin{array}{l}\text { Sample } \\
\text { sources }\end{array}$} & \multirow{2}{*}{$\begin{array}{l}\text { Sample } \\
\text { ID }\end{array}$} & \multicolumn{9}{|c|}{ Trace elements content $(\mu \mathrm{g} / \mathrm{g})$} & \multicolumn{7}{|c|}{ Major elements content (\%) } & \multirow{2}{*}{$\begin{array}{c}\text { TOC } \\
(\%)\end{array}$} & \multirow[b]{2}{*}{ CIA } \\
\hline & & B & $\mathrm{V}$ & $\mathrm{Cr}$ & $\mathrm{Ni}$ & $\mathrm{Cu}$ & $\mathrm{Zn}$ & $\mathrm{Ga}$ & $\mathrm{Sr}$ & $\mathrm{Ba}$ & $\mathrm{SiO}_{2}$ & $\mathrm{Na}_{2} \mathrm{O}$ & $\mathrm{MgO}$ & $\mathrm{K}_{2} \mathrm{O}$ & $\mathrm{CaO}$ & $\mathrm{Fe}_{2} \mathrm{O}_{3}$ & $\mathrm{Al}_{2} \mathrm{O}_{3}$ & & \\
\hline \multirow{30}{*}{$\begin{array}{l}\text { Outcrop of } \\
\text { Longmaxi } \\
\text { shale }\end{array}$} & LMX-1 & 104 & 98 & 66 & 99 & 71 & 136 & 23 & 42 & 778 & 51.9 & 0.2 & 0.6 & 2.5 & 0.2 & 2.1 & 9.2 & & 73 \\
\hline & LMX-2 & 95 & 296 & 58 & 74 & 49 & 108 & 21 & 39 & 721 & 56.4 & 0.2 & 0.6 & 2.0 & 0.1 & 2.2 & 8.0 & & 75 \\
\hline & LMX-3 & 91 & 248 & 68 & 59 & 44 & 76 & 19 & 48 & 767 & 54.3 & 0.3 & 0.5 & 1.9 & 0.2 & 2.2 & 7.8 & & 74 \\
\hline & LMX-4 & 42 & 194 & 59 & 33 & 21 & 56 & 20 & 36 & 742 & 55.8 & 0.1 & 0.5 & 2.1 & 0.1 & 1.0 & 8.2 & & 76 \\
\hline & LMX-5 & 138 & 187 & 63 & 59 & 50 & 92 & 25 & 193 & 437 & 61.8 & 0.3 & 2.2 & 2.0 & 6.1 & 3.0 & 10.1 & & 76 \\
\hline & LMX-6 & 98 & 182 & 71 & 71 & 48 & 98 & 23 & 161 & 456 & 58.2 & 0.4 & 1.2 & 2.2 & 3.8 & 2.1 & 8.4 & 2.3 & 70 \\
\hline & LMX-7 & 98 & 179 & 82 & 57 & 48 & 86 & 27 & 136 & 518 & 59.8 & 0.3 & 1.0 & 2.5 & 2.5 & 2.1 & 9.3 & & 71 \\
\hline & LMX-8 & 92 & 205 & 74 & 65 & 42 & 95 & 26 & 140 & 179 & 52.9 & 0.4 & 1.4 & 2.4 & 3.9 & 2.5 & 9.1 & 2.03 & 70 \\
\hline & LMX-9 & 96 & 189 & 70 & 69 & 43 & 100 & 28 & 150 & 388 & 56.8 & 0.3 & 1.2 & 2.4 & 3.4 & 2.4 & 9.3 & & 71 \\
\hline & LMX-10 & 85 & 115 & 58 & 34 & 39 & 51 & 24 & 95 & 215 & 57.3 & 0.3 & 1.0 & 2.4 & 2.4 & 2.5 & 9.2 & 2.05 & 73 \\
\hline & LMX-11 & 175 & 161 & 90 & 48 & 39 & 91 & 32 & 138 & 328 & 56.0 & 0.6 & 1.7 & 3.1 & 2.7 & 4.0 & 10.9 & & 66 \\
\hline & LMX-12 & 117 & 152 & 91 & 43 & 40 & 78 & 29 & 99 & 149 & 51.9 & 0.7 & 1.6 & 3.2 & 2.0 & 3.3 & 11.2 & 0.92 & 67 \\
\hline & LMX-13 & 133 & 121 & 77 & 33 & 26 & 64 & 29 & 189 & 300 & 40.8 & 0.7 & 2.1 & 2.7 & & & 10.0 & 0.35 & 65 \\
\hline & LMX-14 & 112 & 115 & 88 & 29 & 23 & 57 & 28 & 90 & 384 & 45.7 & 0.8 & 1.6 & 3.1 & 1.3 & 2.9 & 12.1 & 0.18 & 67 \\
\hline & LMX-15 & 126 & 114 & 83 & 30 & 24 & 68 & 28 & 106 & 255 & 66.1 & 0.7 & 1.7 & 3.2 & 1.9 & 3.3 & 12.3 & 0.17 & 68 \\
\hline & LMX-16 & 143 & 125 & 92 & 30 & 26 & 68 & 28 & 102 & 482 & 54.0 & 0.7 & 1.8 & 3.2 & 1.8 & 3.5 & 12.2 & 0.2 & 68 \\
\hline & LMX-17 & 141 & 132 & 98 & 31 & 31 & 95 & 32 & 106 & 429 & 58.3 & 0.6 & 2.0 & 3.4 & 1.8 & 3.6 & 12.5 & 0.18 & 69 \\
\hline & LMX-18 & 169 & 145 & 102 & 29 & 27 & 76 & 34 & 90 & & 55.5 & & & & & & -1 & & 73 \\
\hline & LMX-19 & 170 & 138 & 79 & 28 & 31 & 92 & 33 & 106 & 521 & 64.7 & 0.3 & 2.5 & 3.7 & 2.2 & 4.3 & 14.8 & 0.05 & 75 \\
\hline & LMX-20 & 173 & 144 & 116 & 34 & 32 & 79 & 39 & 69 & 911 & 57.8 & 0.3 & 2.0 & 4.1 & 0.7 & 4.2 & 16.3 & 0.04 & 75 \\
\hline & LMX-21 & 157 & 141 & 103 & 28 & 31 & 83 & 37 & 100 & 632 & 54.8 & 0.4 & 2.1 & 3.8 & 2.0 & 4.0 & 15.2 & 0.05 & 73 \\
\hline & LMX-22 & 181 & 146 & 84 & 40 & 40 & 101 & 38 & 133 & 545 & 51.8 & 0.4 & 2.2 & 3.7 & 2.4 & 4.0 & 14.8 & 0.06 & 73 \\
\hline & LMX-23 & 149 & 131 & 71 & 25 & 28 & 84 & 33 & 171 & 373 & 56.7 & 0.5 & 2.0 & 3.8 & 2.9 & 3.6 & 15.4 & 0.03 & 73 \\
\hline & LMX-24 & 162 & 147 & 105 & 29 & 34 & 73 & 35 & 173 & 465 & 56.4 & 0.4 & 2.1 & 3.6 & 3.6 & 3. & 14.4 & 0.07 & 74 \\
\hline & LMX-25 & 156 & 147 & 104 & 30 & 31 & 84 & 32 & 182 & & & & & & & & & 0.06 & 74 \\
\hline & LMX-26 & 159 & 148 & 92 & 32 & 45 & 78 & 36 & 174 & 228 & 41.4 & 0.4 & 1. & 3. & 4.6 & 3 . & 14.4 & 0.07 & 74 \\
\hline & LMX-27 & 148 & 131 & 102 & 26 & 36 & 77 & 34 & 262 & 487 & 54.2 & 0.4 & & & & & 14.0 & & 74 \\
\hline & LMX-28 & 160 & 158 & 114 & 31 & 29 & 84 & 36 & 137 & 735 & 54.5 & 0.3 & 1.9 & 4.0 & 3.6 & 3.8 & 15.8 & & 75 \\
\hline & LMX-29 & 154 & 138 & 93 & 25 & 21 & 65 & 35 & 130 & 572 & 64.3 & 0.3 & 2.2 & 4.1 & 3.0 & 3.8 & 16.1 & & 75 \\
\hline & Average & 132 & 156 & 85 & 42 & 36 & 83 & 30 & 124 & 484 & 55.5 & 0.4 & 1.6 & 3.1 & 2.6 & & 12.1 & & 72 \\
\hline \multirow[t]{12}{*}{ Well Xiye 1} & Xiye-1 & 164 & 123 & 86 & 47 & 51 & 115 & 22 & 160 & 1009 & 57.4 & 1.1 & 3.0 & 4.0 & 3.5 & 0.9 & 16.5 & 0.87 & 68 \\
\hline & Xiye-2 & 162 & 130 & 89 & 49 & 34 & 340 & 22 & 150 & 1066 & 57.3 & 1.2 & 2.9 & 3.9 & 4.3 & & 15.8 & 1.06 & 66 \\
\hline & Xiye-3 & 313 & 213 & 67 & 80 & 56 & 249 & 22 & 171 & 1448 & 50.9 & 0.9 & 2.3 & 4.8 & 4.6 & 6.8 & 17.8 & 3.35 & 68 \\
\hline & Xiye-4 & 163 & 129 & 92 & 53 & 35 & 116 & 23 & 147 & 1131 & 58.1 & 1.1 & 2.9 & 4.1 & 3.7 & & 16.4 & 1.03 & 67 \\
\hline & Xiye-5 & 123 & 69 & 65 & 40 & 24 & 78 & 18 & 194 & 1052 & 40.8 & 0.7 & 6.1 & 3.0 & 11.3 & 7 . & 12.0 & 0.95 & 68 \\
\hline & Xiye-6 & 161 & 90 & 100 & 55 & 30 & 128 & 25 & 135 & 1135 & 56.6 & 1.0 & .1 & 4. & & & 17.1 & 1.02 & 69 \\
\hline & Xiye-7 & 120 & 141 & 63 & 88 & 57 & 103 & 16 & 162 & 951 & 62.1 & 0.8 & 2.0 & 2.9 & 5.7 & 4.4 & 10.9 & 3.84 & 66 \\
\hline & Xiye-8 & 150 & 88 & 78 & 49 & 33 & 78 & 21 & 166 & 1032 & 56.3 & 1.3 & 2.9 & 3.6 & 5.6 & 5.3 & 14.8 & 1.22 & 64 \\
\hline & Xiye-9 & 85 & 169 & 51 & 93 & 42 & 135 & 13 & 184 & 863 & 68.9 & 0.6 & 1.6 & 2.1 & & 2.9 & 8.0 & 3.61 & 66 \\
\hline & Xiye-10 & 96 & 623 & 80 & 123 & 124 & 152 & 14 & 152 & 828 & 58.7 & 0.6 & 3.1 & 2.4 & 7.0 & 3.3 & 8.4 & 6.46 & 65 \\
\hline & Xiye-11 & 81 & 288 & 51 & 129 & 41 & 193 & 11 & 121 & 789 & 69.2 & 0.6 & 1.7 & 1.9 & 4.8 & 2.8 & 7.2 & 4.95 & 64 \\
\hline & Average & 147 & 187 & 75 & 73 & 48 & 153 & 19 & 158 & 1028 & 57.8 & 0.9 & 2.9 & 3.4 & 5.3 & 5.1 & 13.2 & & 66 \\
\hline \multirow{12}{*}{$\begin{array}{l}\text { Outcrop of } \\
\text { Niutitang } \\
\text { shale }\end{array}$} & NTT-1 & 396 & 120 & 62 & 2.8 & 28 & 14 & 28 & 37 & 46 & 52.4 & & & & & & & & 70 \\
\hline & NTT-2 & 162 & 201 & 81 & 42 & 59 & 69 & 31 & 35 & 291 & 52.7 & 0.0 & 2.1 & 3.8 & 1.2 & 4.2 & 15.3 & & 78 \\
\hline & NTT-3 & 48 & 124 & 48 & 18 & 25 & 16 & 27 & 70 & 98 & 56.7 & 1.6 & 0.5 & 3.2 & 0.1 & 1.2 & 12.4 & & 67 \\
\hline & NTT-4 & 57 & 122 & 91 & 58 & 20 & 28 & 23 & 54 & 269 & 56.1 & 1.3 & 0.5 & 2.9 & 0.1 & 1.5 & 10.7 & & 66 \\
\hline & NTT-5 & 38 & 387 & 101 & 41 & 13 & 19 & 25 & 58 & 118 & 53.7 & 1.8 & 0.4 & 2.9 & 0.3 & 1.0 & 10.7 & & 62 \\
\hline & NTT-6 & 135 & 135 & 84 & 120 & 35 & 162 & 23 & 95 & 628 & 49.1 & 1.8 & 1.1 & 2.7 & 1.4 & 3.2 & 10.1 & & 55 \\
\hline & NTT-7 & 85 & 614 & 101 & 321 & 54 & 568 & 22 & 18 & 538 & 58.1 & 0.0 & 0.7 & 3.2 & 0.0 & 2.4 & 12.1 & & 77 \\
\hline & NTT-8 & 154 & 87 & 55 & 81 & 28 & 276 & 35 & 169 & 365 & 54.3 & 1.0 & 3.7 & 2.4 & 7.0 & 4.3 & 15.5 & & 72 \\
\hline & NTT-9 & 126 & 664 & 95 & 139 & 38 & 46 & 25 & 88 & 689 & 54.7 & 1.5 & 1.0 & 3.1 & 0.9 & 3.1 & 12.1 & & 62 \\
\hline & NTT-10 & 83 & 687 & 49 & 117 & 29 & 234 & 19 & 226 & 238 & 53.2 & 0.1 & 2.2 & 1.0 & 1.7 & 1.5 & 11.2 & & 88 \\
\hline & NTT-11 & 33 & 333 & 233 & 22 & 47 & 63 & 14 & 29 & 504 & 57.8 & 0.0 & 0.5 & 1.9 & 0.4 & 0.8 & 7.2 & & 78 \\
\hline & NTT-12 & 136 & 892 & 104 & 82 & 27 & 63 & 23 & 94 & 387 & 55.2 & 1.4 & 0.6 & 2.7 & 0.5 & 3.7 & 10.2 & & 62 \\
\hline
\end{tabular}


Table 1. (Continued.)

\begin{tabular}{|c|c|c|c|c|c|c|c|c|c|c|c|c|c|c|c|c|c|c|c|}
\hline \multirow{2}{*}{$\begin{array}{l}\text { Sample } \\
\text { sources }\end{array}$} & \multirow{2}{*}{$\begin{array}{l}\text { Sample } \\
\text { ID }\end{array}$} & \multicolumn{9}{|c|}{ Trace elements content $(\mu \mathrm{g} / \mathrm{g})$} & \multicolumn{7}{|c|}{ Major elements content (\%) } & \multirow{2}{*}{$\begin{array}{c}\text { TOC } \\
(\%)\end{array}$} & \multirow[b]{2}{*}{ CIA } \\
\hline & & $\mathrm{B}$ & $\mathrm{V}$ & $\mathrm{Cr}$ & $\mathrm{Ni}$ & $\mathrm{Cu}$ & $\mathrm{Zn}$ & $\mathrm{Ga}$ & $\mathrm{Sr}$ & $\mathrm{Ba}$ & $\mathrm{SiO}_{2}$ & $\mathrm{Na}_{2} \mathrm{O}$ & $\mathrm{MgO}$ & $\mathrm{K}_{2} \mathrm{O}$ & $\mathrm{CaO}$ & $\mathrm{Fe}_{2} \mathrm{O}_{3}$ & $\mathrm{Al}_{2} \mathrm{O}_{3}$ & & \\
\hline & NTT-13 & 18 & 144 & 98 & 1 & 9 & 23 & 20 & 78 & 438 & 47.8 & 1.0 & 0.6 & 2.8 & 0. & 0.5 & 11.2 & & 70 \\
\hline & NTT-14 & 38 & 190 & 87 & 38 & 10 & 17 & 19 & 65 & 471 & 53.1 & 1.7 & 0.4 & 2.6 & 0 . & 1.0 & 10.1 & & 63 \\
\hline & NTT-15 & 17 & 224 & 89 & 29 & 8 & 12 & 19 & 73 & 444 & 56.2 & 1.7 & 0.4 & 2.5 & 0 . & 0.5 & 9.8 & & 63 \\
\hline & Average & 102 & 328 & 92 & 74 & 29 & 107 & 24 & 79 & 368 & 54.1 & 1.0 & 1.0 & 2.7 & 0.9 & 2.7 & 11.2 & & 69 \\
\hline Well & Renye-1 & 131 & 219 & 115 & 60 & 46 & 152 & 23 & 205 & 1274 & 57.7 & 1.3 & 3.2 & 3.2 & 3. & 6.2 & 16.3 & & 68 \\
\hline \multirow[t]{8}{*}{ Renye 1} & Renye-2 & 154 & 2152 & 1687 & 253 & 200 & 197 & 21 & 54 & 2317 & 54.7 & 0.1 & 2.0 & 4.7 & 0.7 & 5.9 & 15.4 & & 74 \\
\hline & Renye-3 & 127 & 176 & 97 & 54 & 63 & 256 & 22 & 196 & 2678 & 58.0 & 1.7 & 3.4 & 3.2 & 2.4 & 7.2 & 16.8 & & 65 \\
\hline & Renye-4 & 103 & 266 & 89 & 182 & 37 & 75 & 18 & 192 & 1018 & 54.4 & 2.1 & 3.3 & 2.4 & 5.0 & 5.3 & 12.1 & & 56 \\
\hline & Renye-5 & 102 & 235 & 94 & 79 & 48 & 184 & 22 & 314 & 984 & 53.4 & 1.7 & 3.2 & 2.7 & 6.6 & 6.1 & 14.4 & & 63 \\
\hline & Renye-6 & 91 & 244 & 94 & 95 & 63 & 173 & 19 & 170 & 1088 & 58.4 & 1.5 & 2.6 & 2.9 & 4.8 & 4.8 & 13.1 & & 62 \\
\hline & Renye-7 & 117 & 313 & 104 & 97 & 66 & 197 & 22 & 167 & 1148 & 56.7 & 1.6 & 3.2 & 3.1 & 3.1 & 6.0 & 15.3 & & 64 \\
\hline & Renye-8 & 69 & 393 & 82 & 394 & 44 & 402 & 13 & 411 & 939 & 56.4 & 1.0 & 2.1 & 2.1 & 9.1 & 4.7 & 8.5 & & 60 \\
\hline & Average & 112 & 500 & 295 & 152 & 71 & 204 & 20 & 214 & 1431 & 56.2 & 1.4 & 2.9 & 3.0 & 4.4 & 5.8 & 14.0 & & 64 \\
\hline
\end{tabular}

Middle Carboniferous sediments in the area. The Upper Carboniferous limestone is mostly eroded and crops out only at a few localities in the region. During the Lower to Middle Permian, in situ weathering zones developed on the Silurian and, after slight uplift, it was subjected to severe lateritic weathering, again, under warm humid climatic conditions.

In the early and late Paleozoic, the South China block experienced several large-scale transgressive events that caused the formation of the following four black shale formations, i.e., the Lower Cambrian, Upper Ordovician-Lower Silurian, Lower Permian, and Upper Permian (Wen et al. 2001). There are mainly three black shale formations developed in the northwestern Guizhou area, the Doushantuo shale formation in the Upper Sinian, the Niutitang shale formation in the Lower Cambrian and the Longmaxi shale formation in the Lower Silurian. However, the latter two shale formations are the main ones we examined in this study. The Niutitang shale mainly developed in the east and south parts of the study area, and the thickness of it varied between 200 and $300 \mathrm{~m}$. The bottom of the Niutitang shale features siliceous rock formation with interbedded carbonaceous shale that generally contains phosphorite, the lower portion of the shale formation is primarily black carbonaceous shale, and the upper portion of this shale formation contains dark gray-green shale with siltstone interbed (Zeng et al. 2013). The Longmaxi shale mostly developed in the northeast part of the study area with the thickness ranging from 50 to $200 \mathrm{~m}$. The black shale at the bottom of the lower section of the Longmaxi shale contains abundant graptolites and is an important hydrocarbon source in various regions of the Yangtze Craton (Wo et al. 2007; Zhang et al. 2009).

\section{Samples and analytical methods}

Samples for this study were collected mainly from outcrop and shale gas wells. The outcrop samples of the Niutitang shale were collected from a profile which is located in Zhunyi City, the core samples of the Niutitang shale were obtained from the well Renye- 1 at a depth of $1272-1347 \mathrm{~m}$. The outcrop samples of the Longmaxi shale were collected from a profile which is located in Xishui County, the core samples of the Longmaxi shale were obtained from the well Xiye- 1 at a depth of $610-648 \mathrm{~m}$ (figure 1). In order to improve the accuracy, outcrop and core samples in the same formation were collected from the bottom to the top, and all samples were fresh.

Total organic carbon (TOC) was obtained by a Leco CS-230 carbon and sulphur analyser at the Geochemistry Laboratory of Yangtze University. The relative standard deviation was more than $5 \%$.

Major elements were determined by XRF spectrometer on fused glass discs. The precision of the major element analysis is $\leq 3 \%$. Trace elements in the black shale were determined by a Perkin-Elmer Sciex ELAN DRC-e ICP-MS at the Nuclear Industry Beijing Geological Research Analysis and Test Research Center. A 50-mg powder sample was dissolved in a high-pressure Teflon bomb with $1 \mathrm{ml} \mathrm{HF}$ and $2 \mathrm{ml} \mathrm{HNO}_{3}$ at $190^{\circ} \mathrm{C}$ for $48 \mathrm{~h}$. After removing $\mathrm{HF}$ by heating, the residue was dissolved in $2 \mathrm{ml}$ $\mathrm{H}_{2} \mathrm{O}$ and $2 \mathrm{ml} \mathrm{HNO}_{3}$ with an appropriate amount of $\mathrm{Rh}$ at $145^{\circ} \mathrm{C}$ for $12 \mathrm{~h}$ (Qi et al. 2000). Rh was used as an internal standard to monitor instrumental drift during the analysis: analytical precision was better than $10 \%$ relative standard deviation.

Mineral compositions were derived from X-ray diffraction analysis. Shale samples were first ground into powder with average particle sizes of 100 mesh 
(0.15 mm), then XRD analysis was performed on a Rigaku D/max-2500PC instrument at $40 \mathrm{kV}$ and $100 \mathrm{~mA}$. The samples were scanned from 5 to $80^{\circ} 2 \theta$ with $0.02^{\circ} 2 \theta$ step size and 2 s step time at room temperature $(293.15 \mathrm{~K})$ and relative humidity, $70 \%$. These analyses were performed at the Nuclear Industry Beijing Geological Research Analysis and Test Research Center.

A combination focused ion beam milling scanning electron microscope (FIB-SEM) was used to investigate the microscopic pores and fractures with a temperature of $24^{\circ} \mathrm{C}$ and a humidity level of $35 \%$ (Zeng et al. 2013; Tang et al. 2014). The pore structure was measured by an ASAP 2020 BET surface area and pore size analyser following the method of Hou et al. (2014) and according to the BET equation calculating shale specific surface area (Brunauer et al. 1938). The porosity and permeability were performed with Ultrapore200A helium porosimeter and ULTRA-PERMTM 200 permeameter following the method of $\mathrm{Li}$ et al. (2014). These tests were performed in the Research Institute of Petroleum Exploration and Development, North China Petroleum Administration.

\section{Results}

\subsection{Major and trace elements}

The results of major and trace elements from the Niutitang and Longmaxi shales are listed in table 1. Most of the trace element enrichment of different levels and the concentration degree of core samples are larger than the outcrop samples. The major elements content of core samples is also greater than the outcrop samples.

\subsection{Mineral composition}

The XRD analysis is presented in table 2 . The content of clay minerals and quartz is the highest, followed by feldspar, calcite, dolomite and pyrite. The quartz content of the outcrop samples from the Longmaxi shale ranges from $17 \%$ to $64 \%$ with the mean value of $34.3 \%$; core samples from the Longmaxi shale range from $33.2 \%$ to $69.9 \%$ with the mean value of $52.4 \%$; outcrop samples form the Niutitang shale range from $14 \%$ to $57 \%$ with an average of $45.6 \%$; core samples from the Niutitang shale range from $50.5 \%$ to $62.2 \%$ with an average of $54.8 \%$. The total clay content in these shales are in the range of $31 \%-55 \%$ with an average of $53.4 \%$ in the outcrop of the Longmaxi shale; $17.9 \%$ to $40.1 \%$ with an average of $26.2 \%$ in the core of the Longmaxi shale; $26 \%-68 \%$ with an average of $43.3 \%$ in the outcrop of the Niutitang shale and $14.9 \%-40 \%$ with an average of $30.6 \%$ in the core of Niutitang shale.

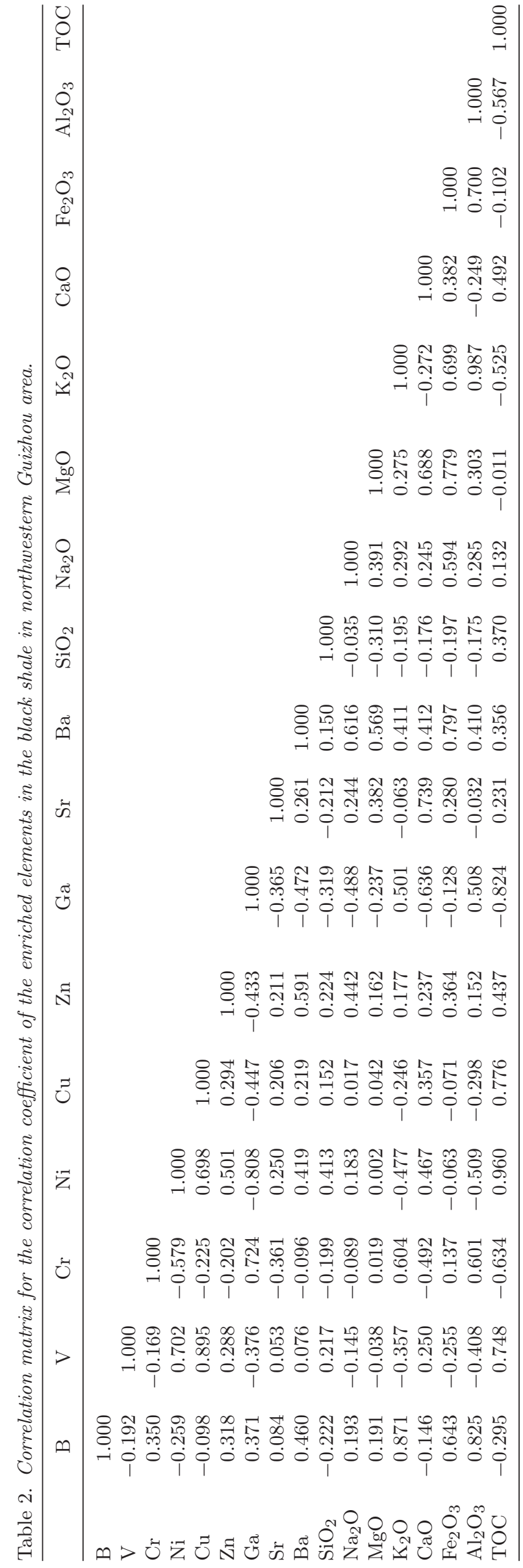




\subsection{Total organic carbon}

Total organic carbon (TOC) data from the shales are listed in table 3 . The results show that TOC values are $3.30 \%$ to $0.18 \%$ from lower to upper of the outcrop of Longmaxi shale; $6.46 \%$ to $0.42 \%$ from lower to upper of the well Xiye 1 of Longmaxi shale; $8.13 \%$ to $0.18 \%$ from lower to upper of the outcrop of Niutitang shale and $10.8 \%$ to
$0.32 \%$ from lower to upper of the well Renye 1 of Niutitang shale.

\subsection{Porosity and permeability}

Results from the porosity and permeability analysis from the shales are listed in table 4 . The effective porosity values of outcrop samples from

Table 3. Mineralogical composition of the black shale in northwestern Guizhou area.

\begin{tabular}{|c|c|c|c|c|c|c|c|}
\hline Sample sources & Sample ID & $\begin{array}{c}\text { Quartz } \\
(\%)\end{array}$ & $\begin{array}{c}\text { Feldspar } \\
\quad(\%)\end{array}$ & $\begin{array}{c}\text { Calcite } \\
(\%)\end{array}$ & $\begin{array}{c}\text { Dolomite } \\
(\%)\end{array}$ & $\begin{array}{c}\text { Pyrite } \\
(\%)\end{array}$ & $\begin{array}{c}\text { Total clay } \\
(\%)\end{array}$ \\
\hline \multirow[t]{17}{*}{ Outcrop of Longmaxi shale } & LMX-3 & 64.0 & 5.0 & & & & 31.0 \\
\hline & LMX-8 & 43.0 & 4.0 & 15.0 & 6.0 & 1.0 & 31.0 \\
\hline & LMX-13 & 34.0 & 11.0 & 5.0 & 10.0 & 1.0 & 39.0 \\
\hline & LMX-15 & 35.0 & 14.0 & 3.0 & & 1.0 & 47.0 \\
\hline & LMX-18 & 34.0 & 7.0 & 3.0 & & 1.0 & 55.0 \\
\hline & LMX-19 & 33.0 & 5.0 & 3.0 & 7.0 & 1.0 & 51.0 \\
\hline & LMX-21 & 37.0 & 5.0 & 4.0 & & 1.0 & 53.0 \\
\hline & LMX-23 & 32.0 & 6.0 & 5.0 & 5.0 & 1.0 & 51.0 \\
\hline & LMX-24 & 33.0 & 6.0 & 7.0 & & 1.0 & 53.0 \\
\hline & LMX-26 & 30.0 & 7.0 & 11.0 & & 1.0 & 51.0 \\
\hline & LMX-27 & 31.0 & 8.0 & 13.0 & & & 48.0 \\
\hline & LMX-29 & 28.0 & 5.0 & 11.0 & & 1.0 & 55.0 \\
\hline & LMX-30 & 31.0 & 1.0 & 18.0 & 15.0 & 1.0 & 34.0 \\
\hline & LMX-31 & 17.0 & 6.0 & 19.0 & 18.0 & 2.0 & 38.0 \\
\hline & LMX-32 & 40.0 & 6.0 & & 6.0 & 1.0 & 45.0 \\
\hline & LMX-33 & 23.0 & 22.0 & 18.0 & & & 32.0 \\
\hline & LMX-34 & 38.0 & 12.0 & 5.0 & & & 43.0 \\
\hline \multirow[t]{11}{*}{ Well Xiye 1} & Xiye-12 & 55.7 & 3.6 & 7.9 & 7.6 & 3.5 & 20.1 \\
\hline & Xiye-13 & 38.9 & 9.3 & 10.4 & 8.1 & 1.6 & 29.9 \\
\hline & Xiye-14 & 33.2 & 4.5 & 12.7 & 6.5 & 4.1 & 37.4 \\
\hline & Xiye-15 & 37.9 & 7.8 & 6.0 & 3.9 & 1.3 & 40.1 \\
\hline & Xiye-16 & 40.2 & 9.4 & 5.8 & 4.4 & 1.5 & 36.3 \\
\hline & Xiye-17 & 69.4 & 2.5 & 3.4 & 2.6 & 2.1 & 18.9 \\
\hline & Xiye-18 & 45.0 & 5.8 & 9.7 & 3.2 & 3.7 & 30.8 \\
\hline & Xiye-19 & 57.6 & 4.6 & 6.4 & 10.4 & 2.0 & 17.9 \\
\hline & Xiye-20 & 69.9 & 2.2 & 7.5 & 3.2 & 1.8 & 15.4 \\
\hline & Xiye-21 & 64.6 & 2.0 & 4.7 & 3.8 & 2.2 & 22.7 \\
\hline & Xiye-22 & 63.5 & 3.3 & 5.1 & 6.7 & 2.6 & 18.8 \\
\hline \multirow[t]{8}{*}{ Outcrop of Niutitang shale } & NTT-16 & 51.0 & 3.0 & & & & 44.0 \\
\hline & NTT-17 & 57.0 & 3.0 & & & & 35.0 \\
\hline & NTT-18 & 57.0 & 1.0 & & & 2.0 & 40.0 \\
\hline & NTT-19 & 37.0 & & 13.0 & 5.0 & 2.0 & 43.0 \\
\hline & NTT-20 & 45.0 & 16.0 & & 3.0 & 10.0 & 26.0 \\
\hline & NTT-21 & 56.0 & 1.0 & & & & 43.0 \\
\hline & NTT-22 & 14.0 & 6.0 & & & 12.0 & 68.0 \\
\hline & NTT-23 & 48.0 & 5.0 & & & & 47.0 \\
\hline \multirow[t]{6}{*}{ Well Renye 1} & Renye-9 & 50.5 & 3.9 & 3.5 & & 2.1 & 40.0 \\
\hline & Renye-10 & 51.0 & 8.9 & 3.1 & & 1.9 & 35.1 \\
\hline & Renye-11 & 51.3 & 6.8 & 4.4 & & 3.8 & 33.7 \\
\hline & Renye-12 & 53.6 & 6.6 & 3.9 & 2.1 & 3.4 & 30.4 \\
\hline & Renye-13 & 62.2 & 7.1 & 4.8 & 6.3 & 4.7 & 14.9 \\
\hline & Renye-14 & 60.1 & 2.4 & 1.4 & 2.4 & 4.0 & 29.7 \\
\hline
\end{tabular}


Table 4. The TOC content of the black shale in northwestern Guizhou area.

\begin{tabular}{|c|c|c|c|}
\hline Sample sources & Sample ID & Depth (m) & TOC $(\%)$ \\
\hline \multirow[t]{12}{*}{ Outcrop of Longmaxi shale } & LMX-44 & & 3.30 \\
\hline & LMX-45 & & 2.33 \\
\hline & LMX-46 & & 2.30 \\
\hline & LMX-47 & & 2.03 \\
\hline & LMX-48 & & 0.95 \\
\hline & LMX-49 & & 0.51 \\
\hline & LMX-50 & & 0.92 \\
\hline & LMX-51 & & 0.35 \\
\hline & LMX-52 & & 0.18 \\
\hline & LMX-53 & & 0.17 \\
\hline & LMX-54 & & 0.20 \\
\hline & LMX-55 & & 0.18 \\
\hline \multirow[t]{12}{*}{ Well Xiye 1} & Xiye-40 & 648 & 6.46 \\
\hline & Xiye-41 & 644 & 4.20 \\
\hline & Xiye-42 & 638 & 3.82 \\
\hline & Xiye-43 & 633 & 3.35 \\
\hline & Xiye-44 & 628 & 1.21 \\
\hline & Xiye-45 & 625 & 0.95 \\
\hline & Xiye-46 & 618 & 1.18 \\
\hline & Xiye-47 & 600 & 0.74 \\
\hline & Xiye-48 & 570 & 0.48 \\
\hline & Xiye-49 & 556 & 0.45 \\
\hline & Xiye-50 & 544 & 0.48 \\
\hline & Xiye-51 & 534 & 0.42 \\
\hline \multirow[t]{5}{*}{ Outcrop of Niutitang shale } & NTT-37 & & 8.13 \\
\hline & NTT-38 & & 6.83 \\
\hline & NTT-39 & & 7.15 \\
\hline & NTT-40 & & 0.59 \\
\hline & NTT-41 & & 0.18 \\
\hline \multirow[t]{5}{*}{ Well Renye 1} & Renye-28 & 1347 & 10.80 \\
\hline & Renye-29 & 1342 & 8.30 \\
\hline & Renye-30 & 1336 & 8.60 \\
\hline & Renye-31 & 1292 & 2.00 \\
\hline & Renye-32 & 1272 & 0.32 \\
\hline
\end{tabular}

the Longmaxi shale range from $2.9 \%$ to $6 \%$ with an average of $4.7 \%$, the effective permeability values range from $0.0058 \times 10^{-3}$ to $0.0185 \times 10^{-3} \mu^{2}$ with an average of $0.0096 \times 10^{-3} \mu \mathrm{m}^{2}$; the effective porosity values of core samples from the Longmaxi shale range from $0.6 \%$ to $4.4 \%$ with an average of $1.8 \%$, the effective permeability values range from $0.0066 \times 10^{-3}$ to $0.1098 \times 10^{-3} \mu^{2}$ with

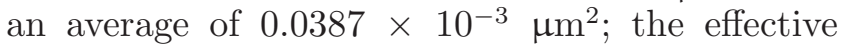
porosity values of outcrop samples in the Niutitang shale range from $0.5 \%$ to $12.9 \%$ with an average of $7.8 \%$, the effective permeability values range from $0.0021 \times 10^{-3}$ to $0.1138 \times 10^{-3} \mu \mathrm{m}^{2}$ with an aver-

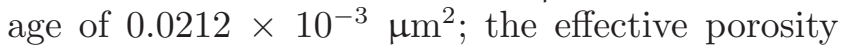
values of core samples in the Niutitang shale range from $0.2 \%$ to $0.8 \%$ with an average of $0.4 \%$, the effective permeability values range from $0.0038 \times$ $10^{-3}$ to $0.0059 \times 10^{-3} \mu^{2}$ with an average of $0.0047 \times 10^{-3} \mu \mathrm{m}^{2}$.

\subsection{BET specific surface}

BET specific surface data from the shales are listed in table 5 . The BET specific surface values of outcrop samples from the Longmaxi shale range from 1.768 to $7.067 \mathrm{~m}^{2} / \mathrm{g}$ with an average of $3.277 \mathrm{~m}^{2} / \mathrm{g}$, the values of core samples from the Longmaxi shale range from 10.735 to $24.646 \mathrm{~m}^{2} / \mathrm{g}$ with an average of $19.745 \mathrm{~m}^{2} / \mathrm{g}$; the values of outcrop samples from 
Table 5. Porosity and permeability of the black shale in northwestern Guizhou area.

\begin{tabular}{|c|c|c|c|c|c|c|}
\hline Sample sources & Sample ID & $\begin{array}{l}\text { Length } \\
(\mathrm{cm})\end{array}$ & $\begin{array}{l}\text { Diameter } \\
\quad(\mathrm{cm})\end{array}$ & $\begin{array}{l}\text { Density } \\
\left(\mathrm{g} / \mathrm{cm}^{3}\right)\end{array}$ & $\begin{array}{c}\text { Effective } \\
\text { porosity }(\%)\end{array}$ & $\begin{array}{l}\text { Effective permeability } \\
\qquad\left(\times 10^{-3} \mu^{2}\right)\end{array}$ \\
\hline \multirow[t]{4}{*}{ Outcrop of Longmaxi shale } & LMX-40 & 2.50 & 2.50 & 2.60 & 4.10 & 0.0058 \\
\hline & LMX-41 & 2.50 & 2.50 & 2.54 & 6.00 & 0.0067 \\
\hline & LMX-42 & 2.50 & 2.50 & 2.62 & 2.90 & 0.0073 \\
\hline & LMX-43 & 2.50 & 2.50 & 2.56 & 5.60 & 0.0185 \\
\hline \multirow[t]{10}{*}{ Well Xiye 1} & Xiye-30 & 2.50 & 2.50 & 2.68 & 1.60 & 0.0136 \\
\hline & Xiye-31 & 2.50 & 2.50 & 2.41 & 2.10 & 0.0617 \\
\hline & Xiye-32 & 2.50 & 2.50 & 2.68 & 0.60 & 0.0367 \\
\hline & Xiye-33 & 2.50 & 2.50 & 2.66 & 2.10 & 0.0111 \\
\hline & Xiye-34 & 2.50 & 2.50 & 2.39 & 4.40 & 0.0253 \\
\hline & Xiye-35 & 2.50 & 2.50 & 2.66 & 1.60 & 0.1098 \\
\hline & Xiye-36 & 2.50 & 2.50 & 2.65 & 1.80 & 0.0994 \\
\hline & Xiye-37 & 2.50 & 2.50 & 2.67 & 1.50 & 0.0066 \\
\hline & Xiye-38 & 2.50 & 2.50 & 2.68 & 0.90 & 0.0069 \\
\hline & Xiye-39 & 2.50 & 2.50 & 2.67 & 1.20 & 0.0071 \\
\hline \multirow[t]{9}{*}{ Outcrop of Niutitang shale } & NTT-28 & 2.50 & 2.50 & 2.65 & 0.50 & 0.0047 \\
\hline & NTT-29 & 2.50 & 2.50 & 2.00 & 8.90 & 0.1138 \\
\hline & NTT-30 & 2.50 & 2.50 & 2.31 & 12.90 & 0.0336 \\
\hline & NTT-31 & 2.50 & 2.50 & 3.00 & 9.60 & 0.0176 \\
\hline & NTT-32 & 2.50 & 2.50 & 2.04 & 6.60 & 0.0067 \\
\hline & NTT-33 & 2.50 & 2.50 & 1.70 & 12.80 & 0.0021 \\
\hline & NTT-34 & 2.50 & 2.50 & 1.64 & 11.30 & 0.0023 \\
\hline & NTT-35 & 2.50 & 2.50 & 2.37 & 6.50 & 0.0070 \\
\hline & NTT-36 & 2.50 & 2.50 & 2.66 & 0.70 & 0.0031 \\
\hline \multirow[t]{8}{*}{ Well Renye 1} & Renye-20 & 2.50 & 2.50 & 2.65 & 0.60 & 0.0039 \\
\hline & Renye-21 & 2.50 & 2.50 & 2.71 & 0.40 & 0.0059 \\
\hline & Renye-22 & 2.50 & 2.50 & 2.74 & 0.40 & 0.0049 \\
\hline & Renye-23 & 2.50 & 2.50 & 2.67 & 0.20 & 0.0038 \\
\hline & Renye-24 & 2.50 & 2.50 & 2.72 & 0.80 & 0.0053 \\
\hline & Renye-25 & 2.50 & 2.50 & 2.67 & 0.40 & 0.0046 \\
\hline & Renye-26 & 2.50 & 2.50 & 2.74 & 0.20 & 0.0052 \\
\hline & Renye-27 & 2.50 & 2.50 & 2.66 & 0.30 & 0.0043 \\
\hline
\end{tabular}

Niutitang shale range from 0.600 to $8.138 \mathrm{~m}^{2} / \mathrm{g}$ with an average of $4.090 \mathrm{~m}^{2} / \mathrm{g}$, the values of core samples from Niutitang shale range from 3.338 to $20.013 \mathrm{~m}^{2} / \mathrm{g}$ with an average of $10.589 \mathrm{~m}^{2} / \mathrm{g}$.

\section{Discussion}

\subsection{Inorganic and organic geochemistry of shale weathering}

The participation of organic matter is a necessary factor for the formation of exogenous deposits (Ye 1996); organic matter or its breakdown products has the close relation with the accumulation of some metal and nonmetal elements (Yin 1999). From table 1, many trace elements in core samples such as $\mathrm{B}, \mathrm{V}, \mathrm{Ni}, \mathrm{Cu}$ and $\mathrm{Zn}$ are higher than the content of outcrop samples (figure 4a). In the TOC and $\mathrm{Cu}, \mathrm{V}, \mathrm{Cr}, \mathrm{Ni}, \mathrm{Zn}, \mathrm{Sr}$ diagram (figure 3), the TOC content of the black shale presents a positive correlation with some trace elements $(\mathrm{Cu}, \mathrm{V}, \mathrm{Ni}$, $\mathrm{Zn}$ ). $\mathrm{Cu}, \mathrm{V}, \mathrm{Ni}$ especially (table 2), showed the adsorption and complexation of organic matter to some elements that led to the enrichment of related elements. Moreover, when the core samples are compared with the outcrop samples, the loss of these trace elements are not obvious with the low TOC content, but the loss degree goes up with increased TOC content. These suggest that the progressive weathering of the black shale releases elements during sulphide and organic matter oxidation. Moreover, loss of trace elements in shale with high TOC content is greater than in shale with low TOC content in the weathering process (figure 3 ). 

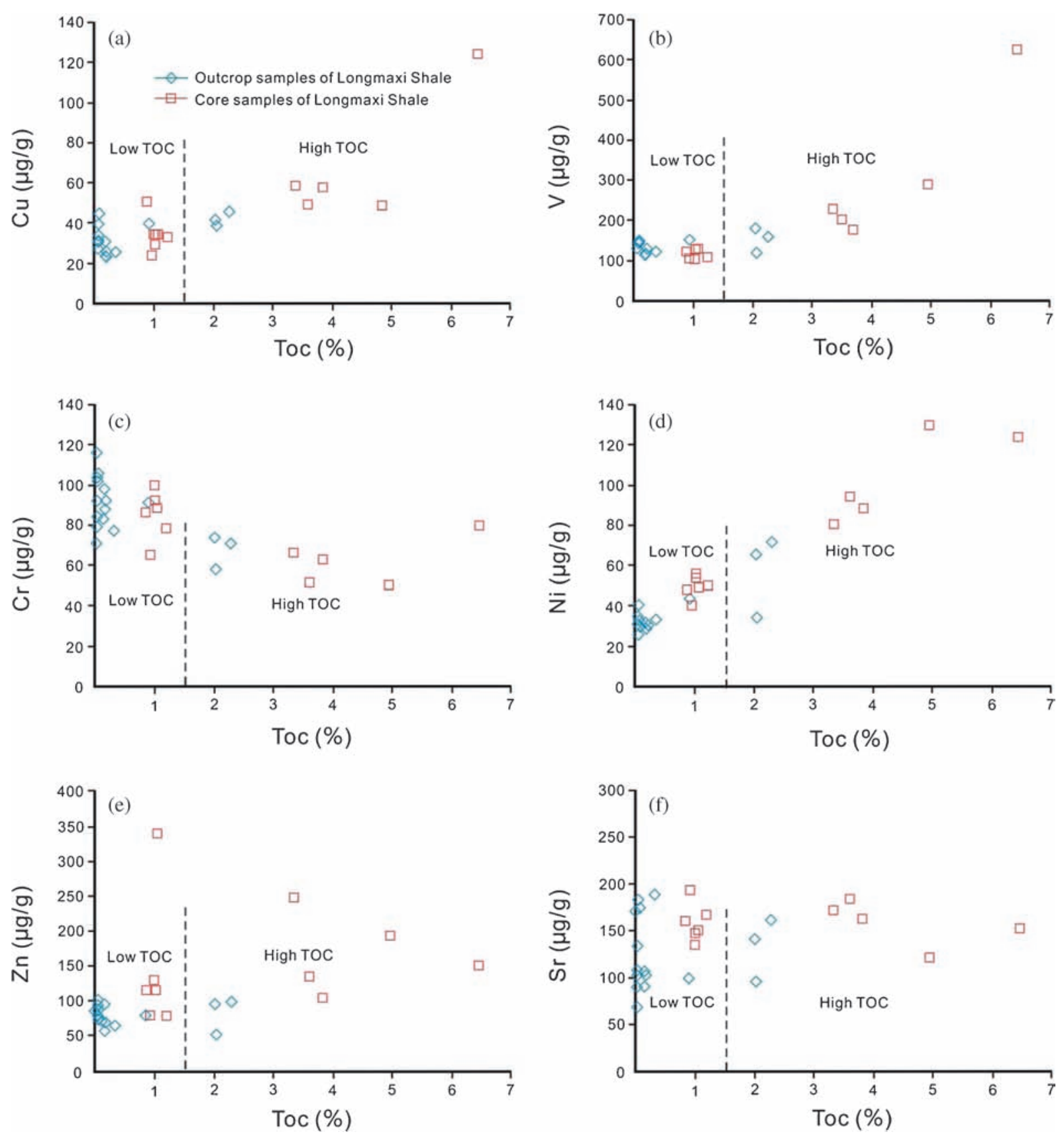

Figure 3. The cross plots of TOC content vs. the $\mathrm{Cu}(\mathbf{a}), \mathrm{V}(\mathbf{b}), \mathrm{Cr}(\mathbf{c}), \mathrm{Ni}(\mathbf{d}), \mathrm{Zn}(\mathbf{e})$ and $\mathrm{Sr}(\mathbf{f})$.

Chemical weathering process can be divided into three periods according to the elements activity order in the rock: early stage of the relative release of $\mathrm{Ca}, \mathrm{Na}$, middle stage of the relative release of $\mathrm{K}$ and late stage of the relative release of Si (Nesbitt and Young 1984). The major elements of shale also present different degrees of leaching, $\mathrm{Na}, \mathrm{Ca}, \mathrm{Mg}$ and $\mathrm{Fe}$ in the core samples are significantly higher than in the outcrop samples and there is also a slight loss of $\mathrm{K}$ (figure $4 \mathrm{~b}$ ). $\mathrm{Ca}$ and $\mathrm{Na}$ suffered strong leaching with the dissolution of calcite and plagioclase minerals, followed by $\mathrm{K}$ which suffered major leaching with the weathering of K-feldspar and mica.
The chemical index of alteration (CIA) is well established as a method of quantifying the degree of source weathering (Nesbitt and Young 1982, 1984). The paleoweathering index of the Lower Cambrian and Lower Silurian shales (core samples) indicates a sediment supply from weakly weathered sources with CIA values of 56-74 with an average of 64 and 64-69 with an average of 66 , respectively. However, the Niutitang and Longmaxi shales from outcrop samples show strongly weathered sources with the CIA values of 55-88 with an average of 69 and $65-76$ with an average of 72 , respectively. On an A-CN-K ternary plot (figure 5), most data cluster near the A-K edge, near illite composition, and 

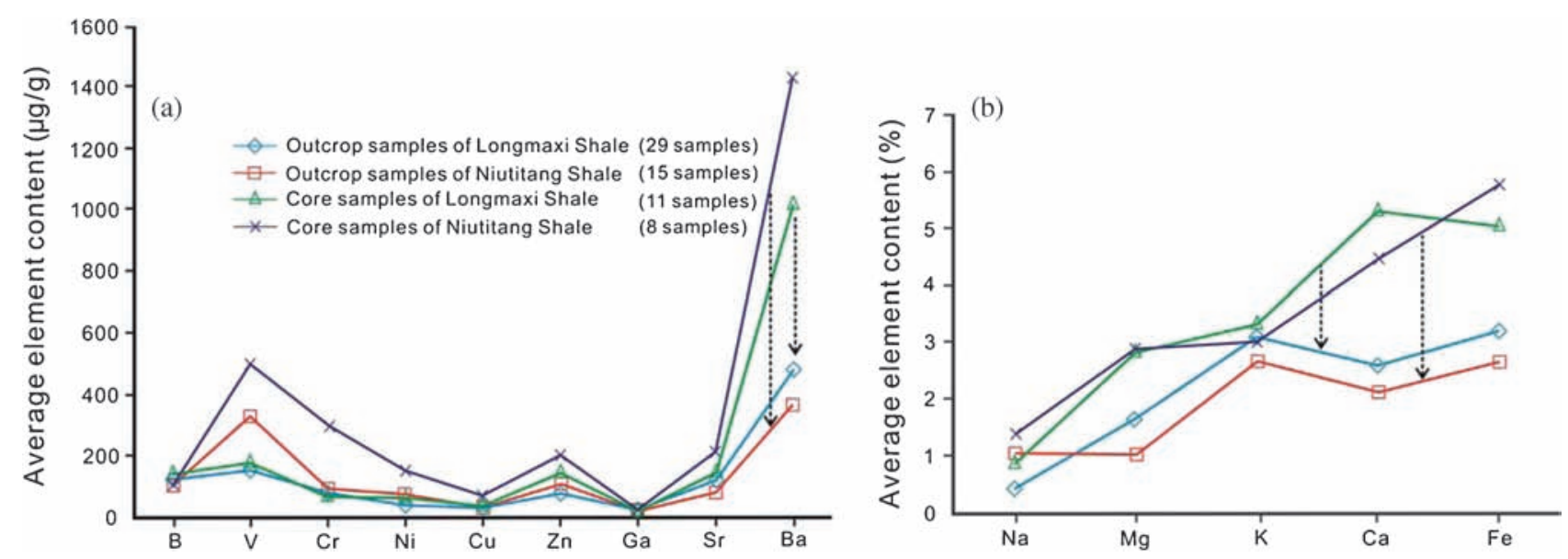

Figure 4. The trace element content (a) and major element content (b) of the Lower Paleozoic black shale in northwestern Guizhou Province.

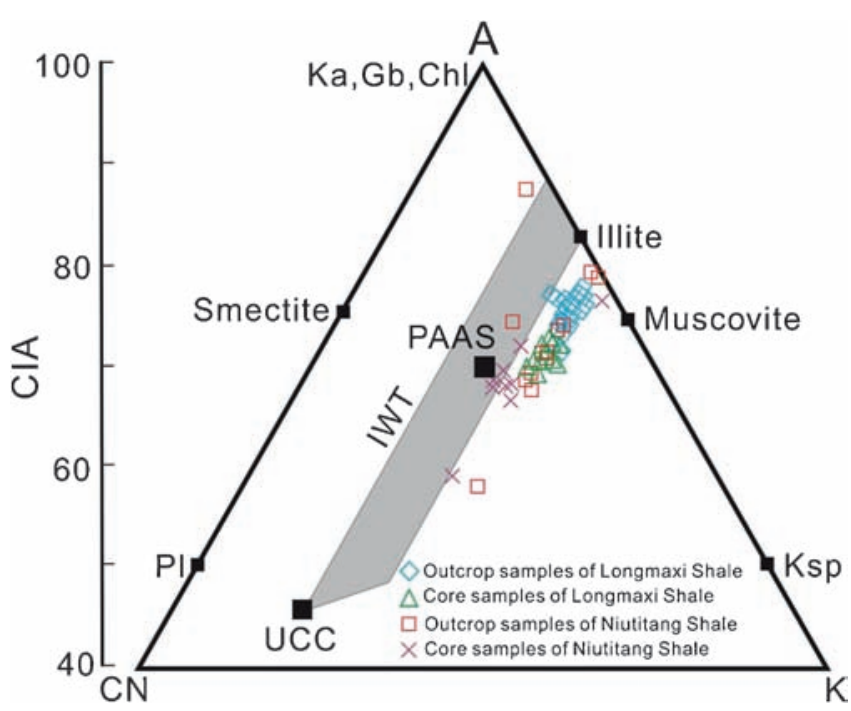

Figure 5. A-CN-K plots (Nesbitt and Young 1984) for black shale samples in northwestern Guizhou area. $\mathrm{A}: \mathrm{Al}_{2} \mathrm{O}_{3}, \mathrm{CN}$ : $\mathrm{CaO}^{*}+\mathrm{Na}_{2} \mathrm{O}$, K: $\mathrm{K}_{2} \mathrm{O}$. Mineral compositions - Pl: plagioclase; Ksp: K-feldspar; Ka: kaolinite; Gb: gibbsite; Chl: chlorite; UCC: upper continental crust; PAAS: post-Archean Australian shale (Taylor and McLennan 1985).

spread towards the A apex, significantly greater than the post-Archean Australian shale (PAAS) for average shales (Taylor and McLennan 1985). The data of the Niutitang and Longmaxi shales all plot along the same weathering trend line, which implies that they are derived from a common lithology.

Organic carbon as one of the basic index of the abundance of organic matter can indirectly reflect the number of original organic matter and represent the abundance of organic matter in rocks (Shang et al. 1990). The samples used in the study of organic matter leaching are collected from lower to upper of the Longmaxi and Niutitang shales, there is a one-to-one correspondence between outcrop samples and core samples of the same shale

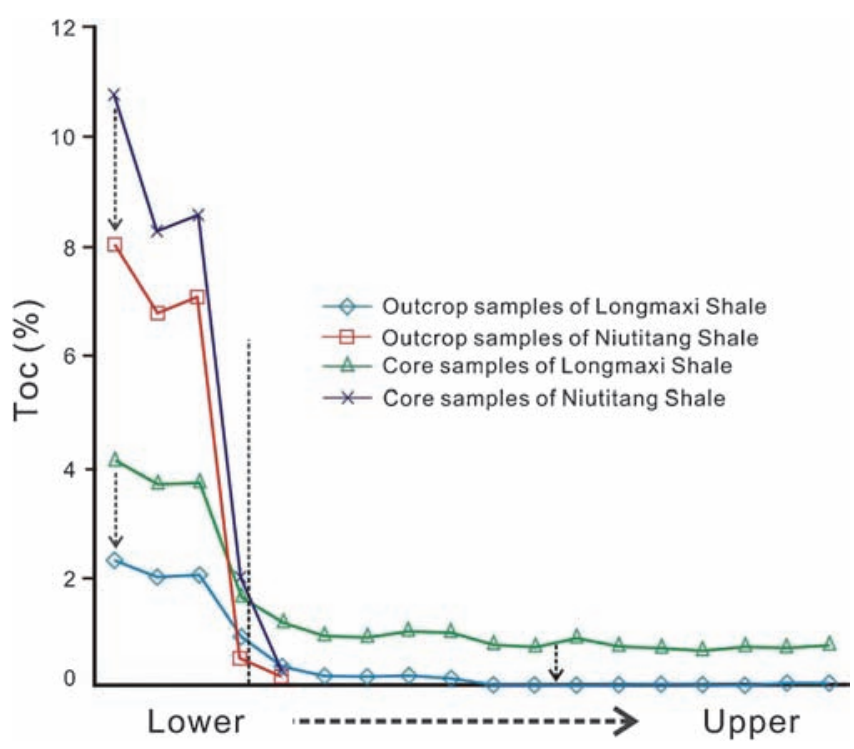

Figure 6. The diagram showing the TOC content varieties with the black shale from lower to upper in the same formation.

formation. The TOC content of these two shales diminishes gradually from lower to upper, the greater TOC content in the core samples, the more loss of organic matter in the outcrop samples (figure 6). In the TOC content of outcrop samples and core samples diagram (figure 7), we found that the data of the two types of samples show a good linear relationship, the $\mathrm{TOC}_{(\text {core })}=1.173 \times$ $\mathrm{TOC}_{(\text {outcrop) }}+0.6342$. Tang et al. (unpublished) studied the weathering process of the Lower Triassic shale in the Ordos Basin wherein they indicated that the average value of TOC from core samples is $2.22 \%$ and the average value of TOC from outcrop samples is $1.32 \%$. These data are in good agreement with the linear relationship observed in this study. It suggested that the weathering 
process has a significant impact on organic matter abundance, moreover, the relationship between TOC content of core samples and outcrop samples can be used to predict the TOC content of black shale underground, by the data of outcrop samples. In plots of TOC and TOC loss rate (TOC $\left._{(\text {core })-} \mathrm{TOC}_{(\text {outcrop })} / \mathrm{TOC}_{(\text {core })}\right)$ vs. depth, the

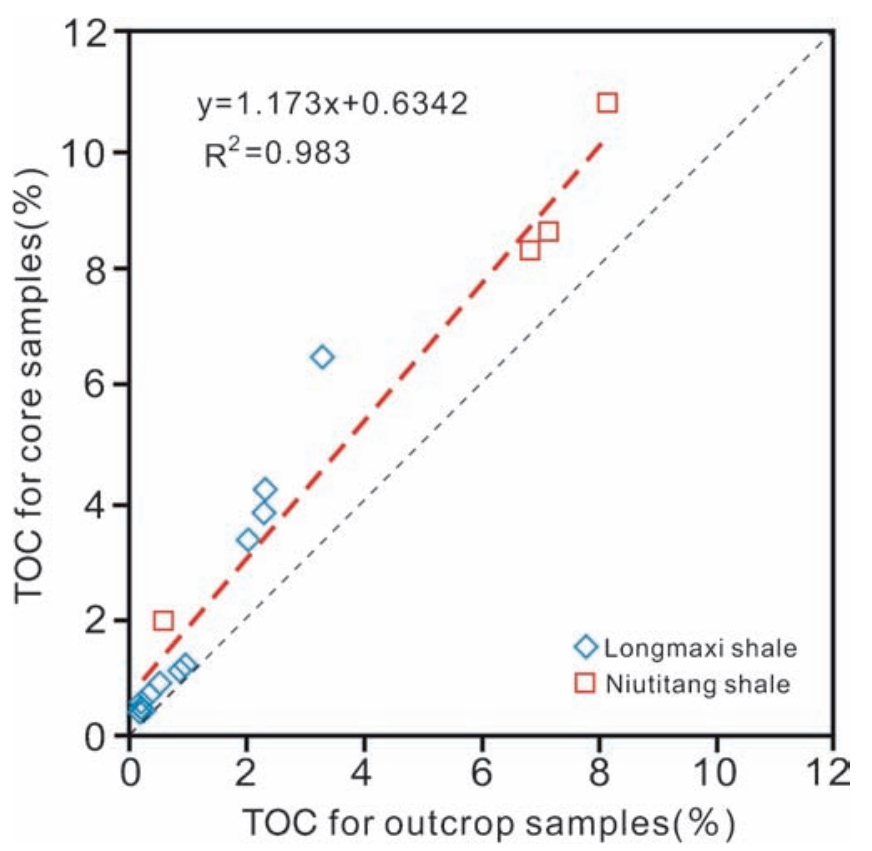

Figure 7. The cross plots of TOC content for outcrop samples vs. the TOC content for core samples.

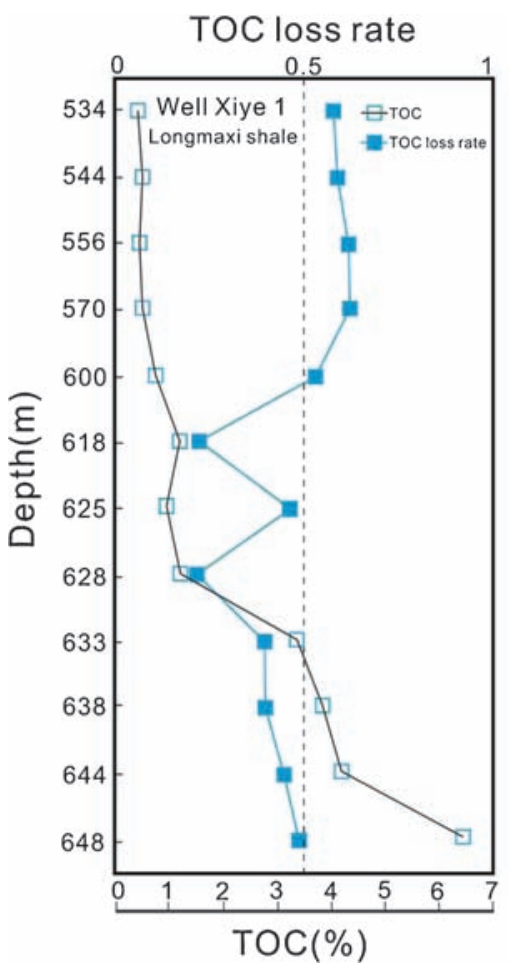

TOC of black shale was observed to significantly increase with increasing depth, but those of TOC loss rate is not monotone increasing. The loss rate of TOC in black shales range from $18 \%$ to $70 \%$ with an average of $43 \%$ and the Longmaxi and Niutitang shales all show that the TOC loss rate of black shale with low TOC content is more than those with high TOC content during weathering process (figure 8).

\subsection{Mineralogical composition characteristics of shale weathering}

Brittle mineral content is an important factor which influences the matrix pore, the degree of micro fracture development, the hydrocarbon content and the way of fracturing of shale. In addition to quartz, feldspar and dolomite are also brittle mineral components of black shales (Nelson 1985). The higher the content of brittle minerals such as quartz, feldspar and calcite in shale, the more conducive they are to form natural and induced cracks under the action of external force (Zou et al. 2010). The mineral composition of shale samples is illustrated in figure 9. It is clear that the brittle mineral content in the core samples is significantly higher than outcrop samples but clay mineral is lower than the outcrop samples. Major elements ( $\mathrm{Si}, \mathrm{Al}$, and $\mathrm{Mg}$ ) change little across the weathering profile. In contrast, $\mathrm{Na}$ and $\mathrm{K}$ are depleted relative to the concentrations predicted by the abundance of the mineral phases. Feldspars, illite and

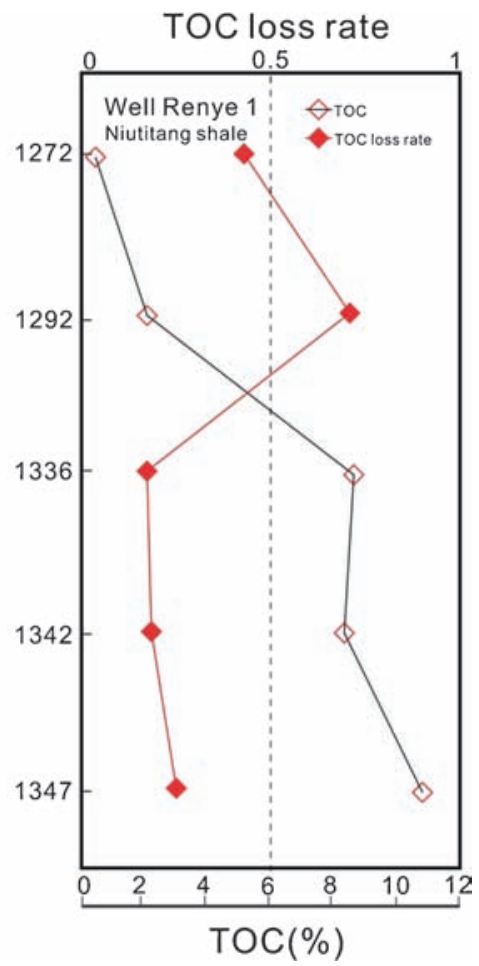

Figure 8. Plots showing the depth variation for TOC and TOC loss rate. 
illite-smectite host these elements whose low ratios may represent incongruent dissolution and change in the interlayer cation abundances in response to the acidic weathering conditions.

Because the black shale contains significant amounts of pyrite, the result is acidic weathering that prevails across the outcrop and controls much of the mineral alteration and secondary mineral formation. In certain intervals, a subtle increase in $\mathrm{pH}$ can result in profound mineral alteration. Along with acidity, $\mathrm{SO}_{4}$ and $\mathrm{Fe}$ (II) are generated during pyrite oxidation. Sulphate forms secondary minerals, but many of these are relatively soluble in water and eventually are eluted from the weathering profile (Tuttle and Breit 2009; Tuttle et al. 2009). This may be the main factor leading to the loss of Fe, in the outcrop shale samples.

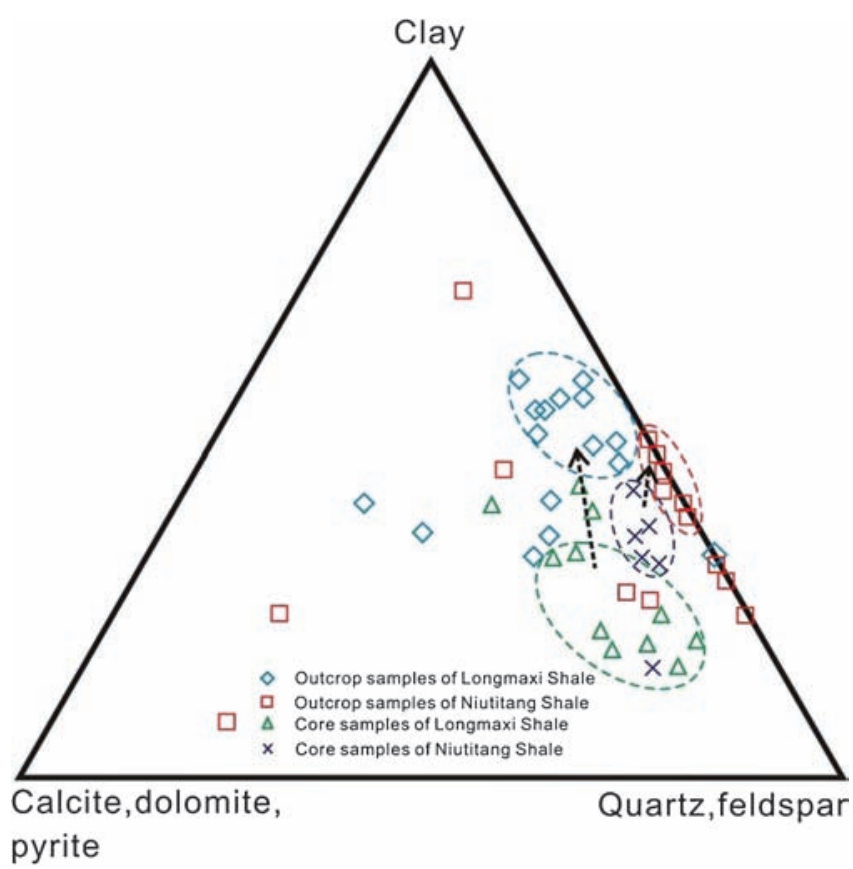

Figure 9. Mineralogical composition of the black shale in northwestern Guizhou area.

\subsection{Petrophysical changes of shale weathering}

The opinion that 'the higher the porosity, better the permeability' has always been serving as a major guideline in the production operation of medium-high porosity and permeability reservoirs. In low porosity and low permeability reservoirs, however, there is often a conflict with this point of view (Pittman 1992). Figure 10 reveals that with the increase of porosity, the changes of permeability are not very noticeable both in core and outcrop samples. There are a few abnormal permeability values, this may be the existence of natural fracture which resulted in increased permeability value. Wildman et al. (2004) attribute porosity and permeability in shale to organic matter oxidation. By comparing the core and outcrop samples, not only was the porosity of outcrop samples found to increase after weathering leaching (figure 11), the data also showed that the porosity of core samples are more concentrated and mostly distributed in a relatively narrow range of $0.2 \%$ to $2 \%$, whereas the porosity values of outcrop samples are scattered from $3 \%$ to $14 \%$, which may be related to the pore structure of shales. Additionally, the Niutitang shale in the lower Cambrian is older and has a more compact structure than that of the Longmaxi shale in the Lower Silurian where the increment of porosity is larger after weathering. The cause of this result could be that the Niutitang shale has a higher content of organic matter and sulphide minerals, and the buffering of organic matter oxidation by pyrite that occurs in the shale reacts as an electron donor much faster than organic matter (Petsch et al. 2000). In addition, secondary pores created by the dissolution of unstable minerals such as feldspar and calcite constitute a part of the reservoir space of the shale reservoir and increase the porosity of shale. Therefore, we infer that weathering effect on the porosity and permeability of black shale has certain regularity: black shale weathering has strong heterogeneity, and the

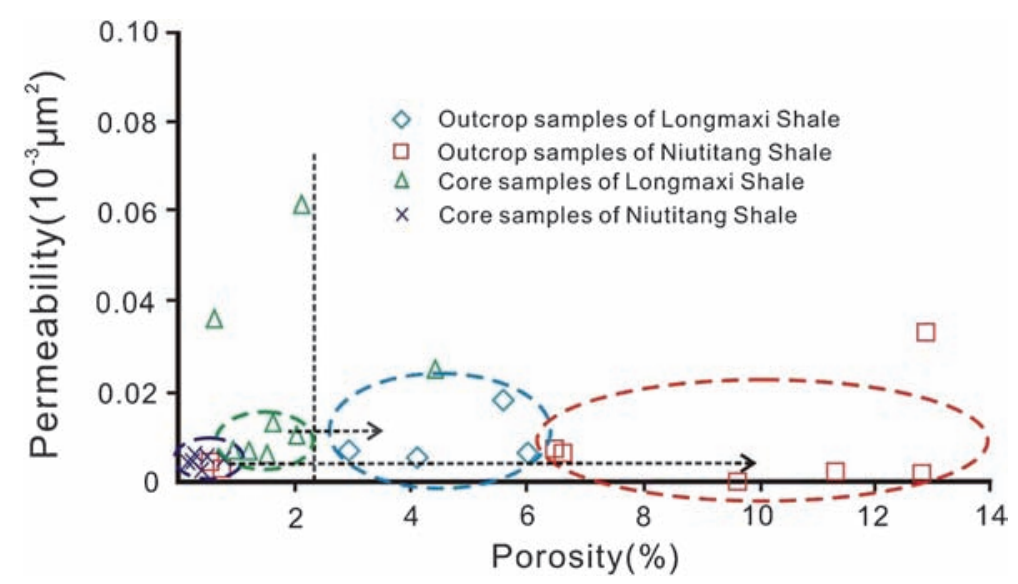

Figure 10. Porosity and permeability diagram for the black shale in northwestern Guizhou area. 

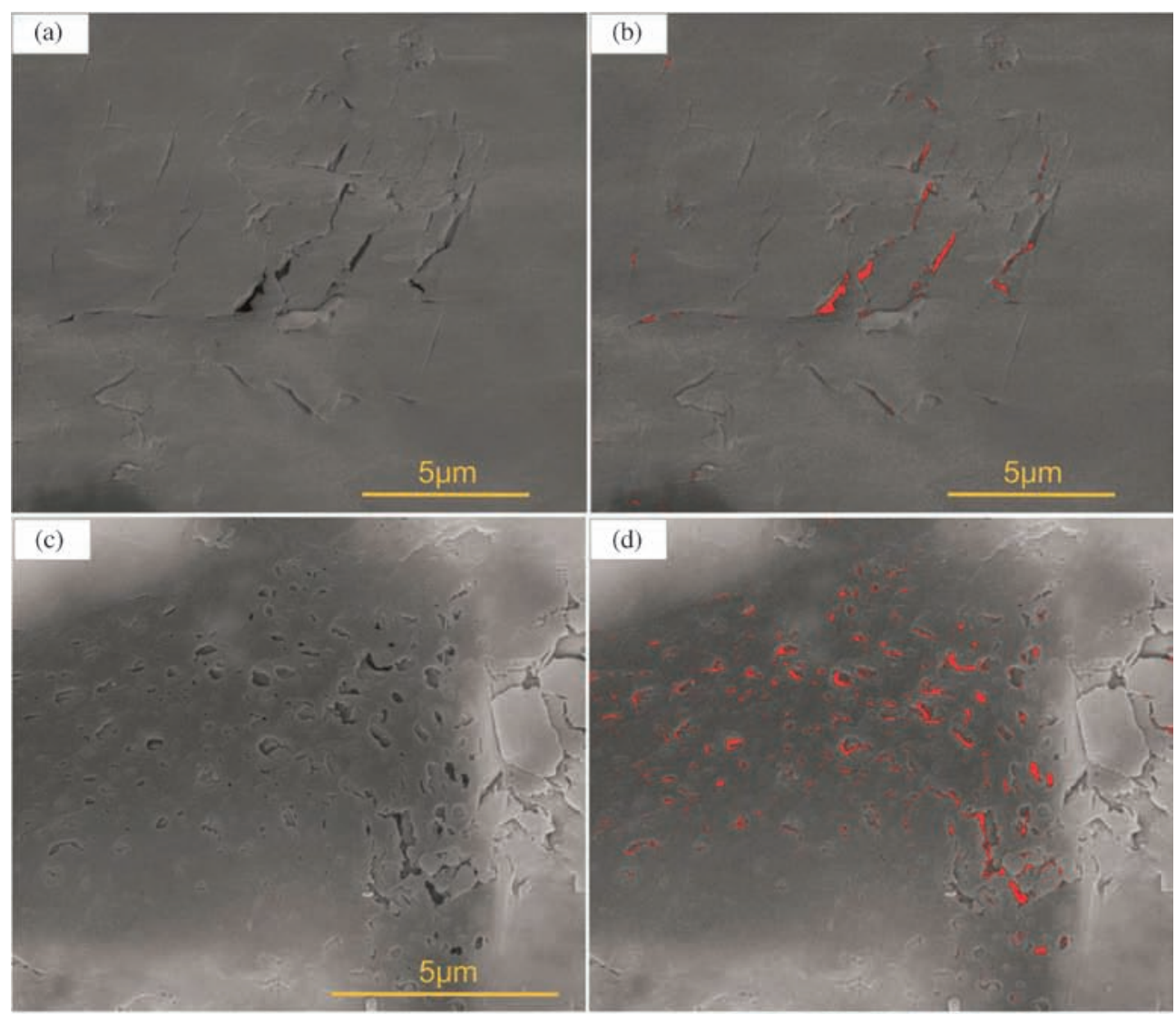

(d)
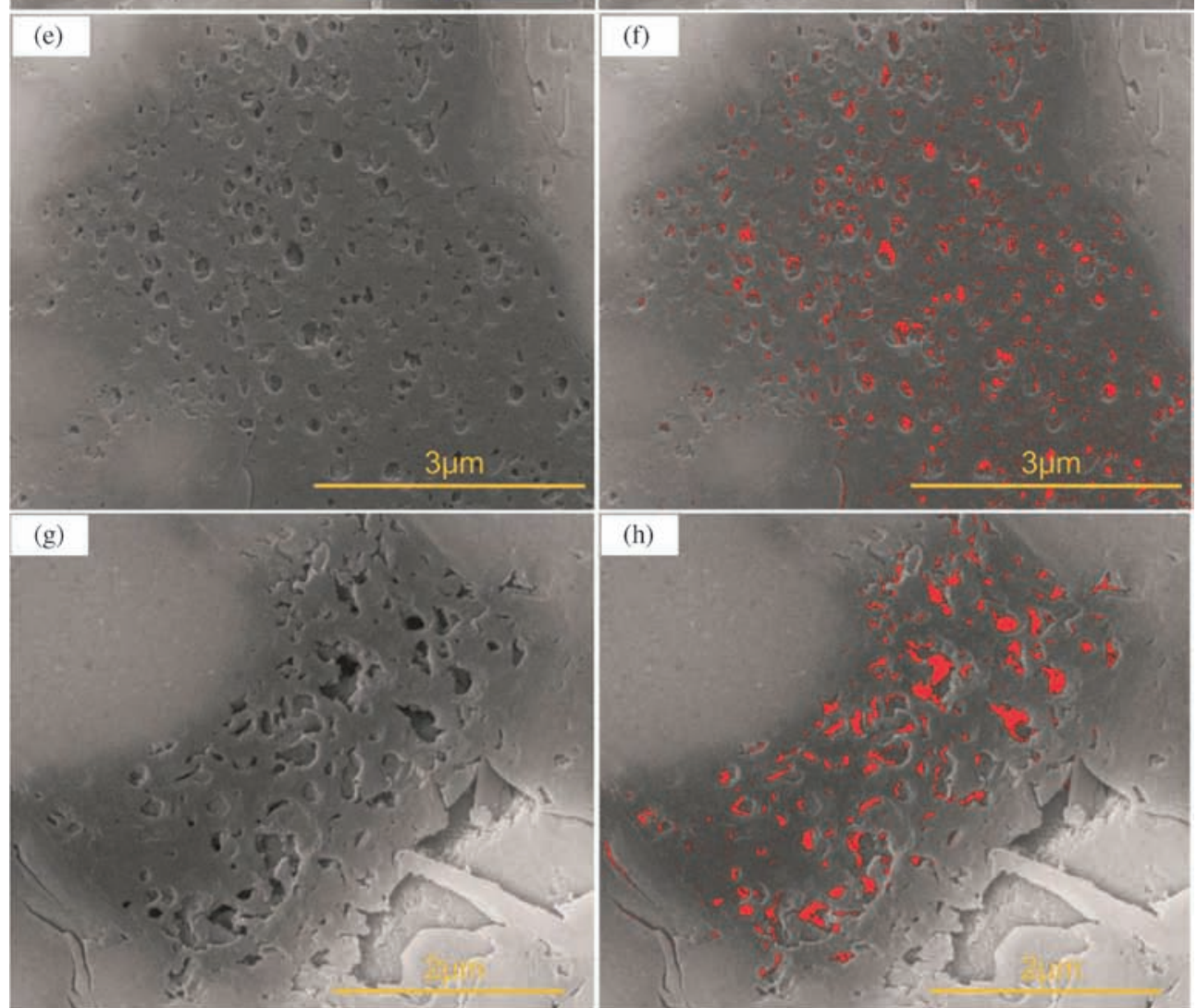

Figure 11. SEM photographs of the black shale in northwestern Guizhou area. (a, b) Core sample of Niutitang shale, well Renye 1, $1325 \mathrm{~m}$, facial porosity $=0.67 \%$. (c, d) Outcrop sample of Niutitang shale, facial porosity $=1.3 \%$. (e, f) Core sample of Longmaxi shale, well Xiye 1, $643.5 \mathrm{~m}$, facial porosity $=3.67 \%$. (g, h) Outcrop sample of Longmaxi shale, facial porosity $=7.46 \%$. 
higher the organic matter and sulphide mineral content in shale, the more obvious is the increase of the porosity after weathering modification, but the change of permeability is very limited.

Previous research on black shale shows that $85 \%$ of organic carbon is closely related to the specific surface area of the rock (Weiler and Mills 1965; Suess 1973; Tanoue and Handa 1979; Mayer 1994). As illustrated in figure 12(a), BET surface area (the total surface area of a solid calculated by the BET (Brunauer, Emmett, and Teller) equation) of black shale and TOC content present obvious positive correlation, it illustrates that TOC is the main controlling factor of the specific surface area. Because the internal porosity of organic matter is very developed and provides a large specific surface area, this is consistent with the opinion of Ross et al. (Ross and Bustin 2008). Through the comparisons of the core sample and outcrop samples (table 6), it is not hard to find that the core sample has a high TOC content, which has bigger BET surface area, but the specific surface area is
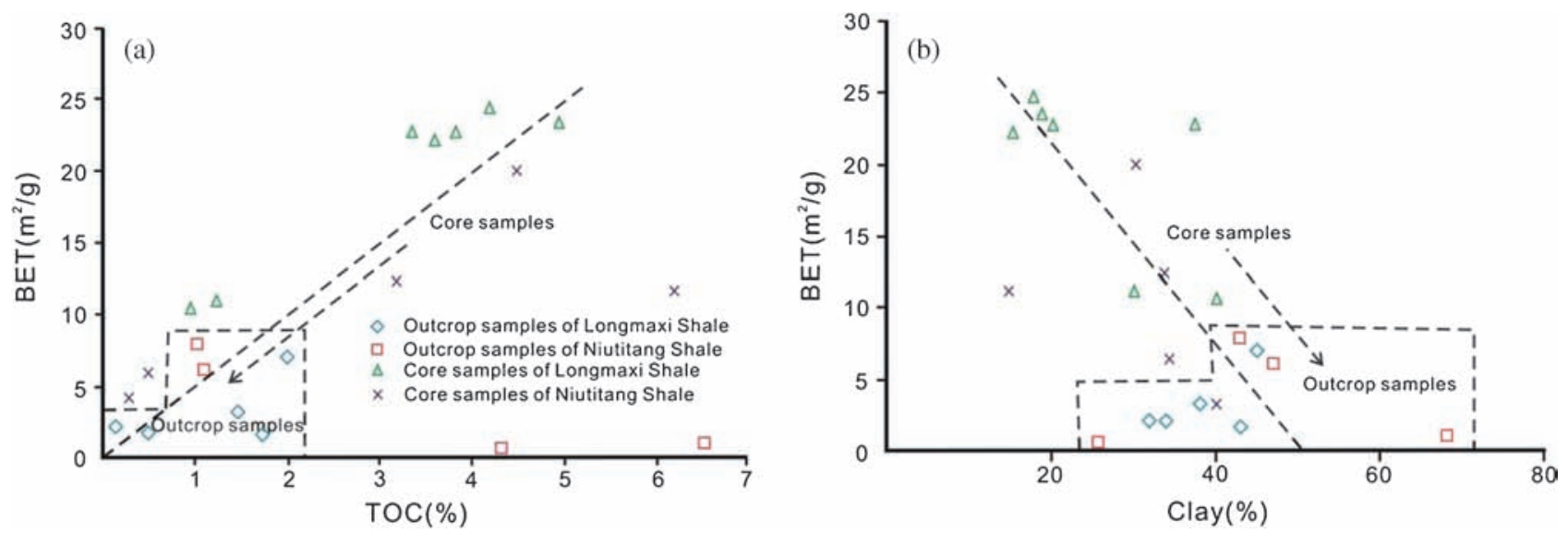

Figure 12. The cross plots of BET surface area vs. the TOC content (a) and clay mineral content (b).

Table 6. BET surface area of the black shale in northwestern Guizhou area.

\begin{tabular}{|c|c|c|c|c|c|}
\hline Sample sources & Sample ID & Quartz & $\begin{array}{c}\text { Total clay } \\
(\%)\end{array}$ & $\begin{array}{l}\text { TOC } \\
(\%)\end{array}$ & $\begin{array}{c}\text { BET surface area } \\
\left(\mathrm{m}^{2} / \mathrm{g}\right)\end{array}$ \\
\hline \multirow[t]{5}{*}{ Outcrop of Longmaxi shale } & LMX-35 & 31.00 & 34.00 & 1.72 & 2.111 \\
\hline & LMX-36 & 17.00 & 38.00 & 1.46 & 3.282 \\
\hline & LMX-37 & 40.00 & 45.00 & 1.99 & 7.067 \\
\hline & LMX-38 & 23.00 & 32.00 & 0.13 & 2.158 \\
\hline & LMX-39 & 38.00 & 43.00 & 0.47 & 1.768 \\
\hline \multirow[t]{7}{*}{ Well Xiye 1} & Xiye-23 & 37.90 & 40.10 & 0.95 & 10.735 \\
\hline & Xiye-24 & 55.70 & 20.10 & 3.84 & 22.818 \\
\hline & Xiye-25 & 38.90 & 29.90 & 1.22 & 11.272 \\
\hline & Xiye-26 & 33.20 & 37.40 & 3.35 & 22.906 \\
\hline & Xiye-27 & 57.60 & 17.90 & 4.20 & 24.646 \\
\hline & Xiye-28 & 69.90 & 15.40 & 3.61 & 22.275 \\
\hline & Xiye-29 & 63.50 & 18.80 & 4.95 & 23.566 \\
\hline \multirow[t]{4}{*}{ Outcrop of Niutitang shale } & NTT-24 & 45.00 & 26.00 & 4.34 & 0.600 \\
\hline & NTT-25 & 56.00 & 43.00 & 1.03 & 8.138 \\
\hline & NTT-26 & 14.00 & 68.00 & 6.53 & 1.237 \\
\hline & NTT-27 & 48.00 & 47.00 & 1.10 & 6.386 \\
\hline \multirow[t]{5}{*}{ Well Renye 1} & Renye-15 & 50.50 & 40.00 & 0.30 & 3.338 \\
\hline & Renye-16 & 51.00 & 35.10 & 0.50 & 5.994 \\
\hline & Renye-17 & 51.30 & 33.70 & 3.20 & 12.378 \\
\hline & Renye-18 & 53.60 & 30.40 & 4.50 & 20.013 \\
\hline & Renye-19 & 62.20 & 14.90 & 6.20 & 11.221 \\
\hline
\end{tabular}




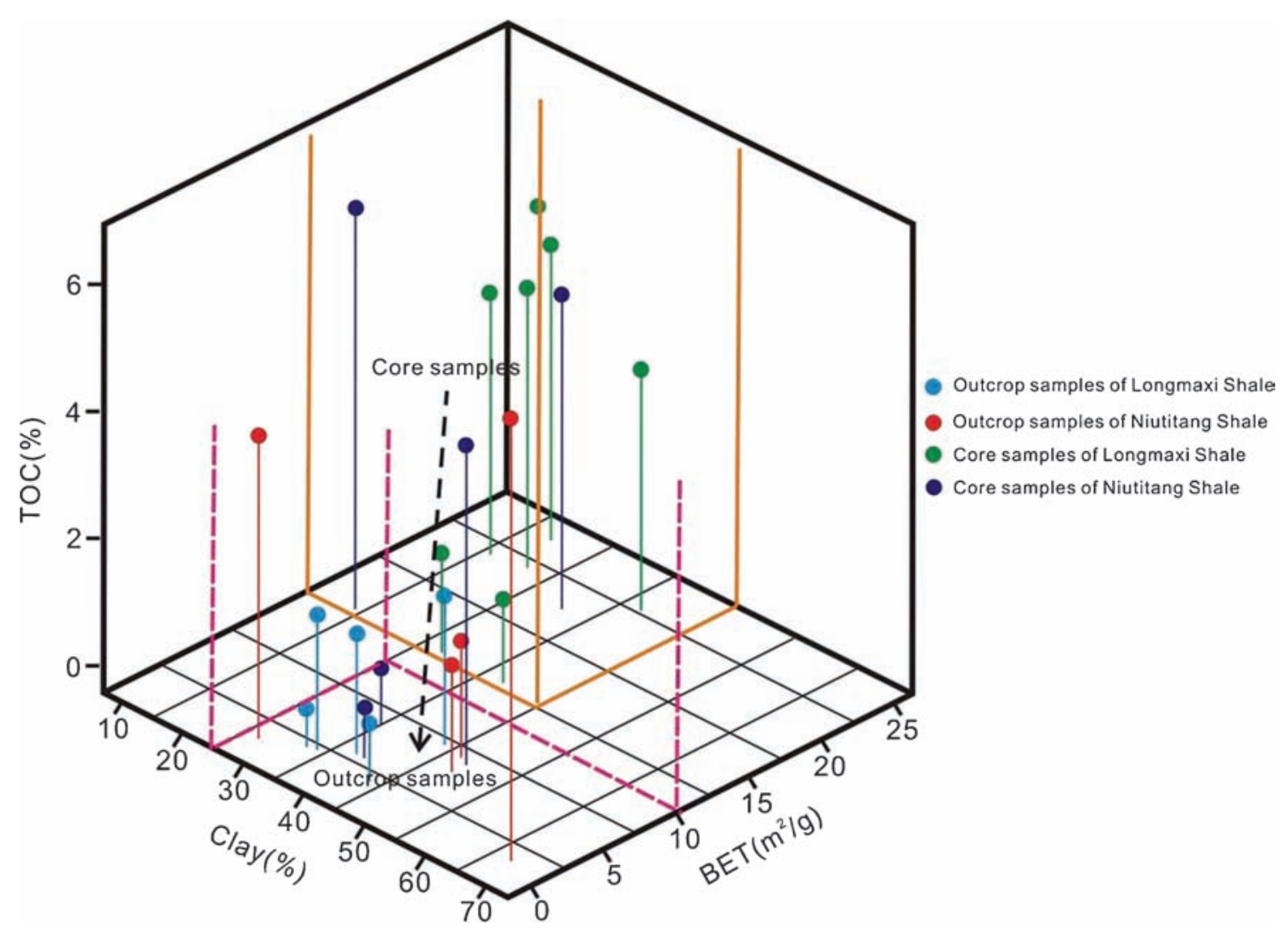

Figure 13. Three-dimensional plots relating BET surface area, TOC content and clay mineral content.

reduced due to the loss of organic matter in outcrop samples. Previous studies have shown the control action of TOC to BET surface area is stronger than the effect of clay minerals content to BET surface area, usually, the content of clay minerals in shale is low, the TOC content is relatively high (Cao et al. 2014). The increase of BET surface area caused by the increase of TOC is obscured by the decrease of BET surface area caused by the decrease of the content of clay minerals (figure $12 \mathrm{~b}$ ). However, under the condition of the same TOC content, with the increase of the content of clay minerals, BET surface area also has a tendency to increase. Therefore, because of the higher TOC content and relatively lower content of clay minerals in core samples compared with the outcrop samples, the increase of BET surface area brought by the high TOC content of the core samples makes up for the reduce of BET surface area caused by the decrease of the content of clay minerals (figure 13), thus makes the BET surface area of core samples greater than the outcrop samples.

In summary, the TOC content played a decisive role in the BET surface area of black shales, it also suggests that the loss of organic matter through weathering process is the key factor which leads to the differences between the core and the outcrop samples.

\section{Conclusions}

(1) The major and trace element results show that the trace elements of shale have varying degrees of loss in the process of weathering and the migration quantity of Niutitang shale is higher than that of Longmaxi shale, the major elements such as $\mathrm{Na}, \mathrm{Ca}, \mathrm{Mg}$, Fe reduced as the dissolution of minerals such as pyrite, feldspar and calcite.

(2) The loss of organic carbon in samples with high TOC content is larger than those samples with low TOC content. The loss rate of TOC in black shales range from $18 \%$ to $70 \%$ with an average of $43 \%$, and the linear relationship between TOC content of core samples and outcrop samples indicated that $\mathrm{TOC}_{(\text {core })}=1.173 \times 1 \mathrm{TOC}_{(\text {outcrop })}+$ 0.6342 .

(3) The increment of porosity of the Niutitang shale with more sulphide and organic matter is larger than the Longmaxi shale, but the permeability changes little with the increase of porosity, suggesting the organic matter and sulphide oxidation are the main factors of the change of porosity and permeability during black shale weathering process.

(4) Combined with the results of the mineral composition, TOC content and BET surface area in 
black shale, the data shows that the TOC content played a decisive role in the BET surface area of black shale.

\section{Acknowledgements}

This work was supported by the National Natural Science Foundation of China (41102088 and 41272167) and the Fundamental Research Funds for the Central Universities, the research of shale gas resources evaluation and block optimising selection in Guizhou Province (GZSYYQZYDC2012-05) and China Geological Survey (12120115007201).

\section{References}

Brunauer S, Emmett P H and Teller E 1938 Adsorption of gases in multi-molecular layers; J. Am. Chem. Soc. 60 309-319.

Cao X M, Yu B S, Li X T, Sun M D and Zhang L 2014 Reservoir characteristics and evaluation on logging of the Lower Cambrian gas shale in southeast Chongqing: A case study of Well Yuke 1 and Well Youke 1; Acta. Petrol. Sin. 35233 - 244 (in Chinese with English abstract).

Chen J Y, Tang D Q and Yang C P 2003 Advances in the research and exploration of unconventional petroleum systems; Geo. Sci. Tech. Info. 22 55-59 (in Chinese with English abstract).

Chorley R J 1969 The role of water in rock disintegration; Intro. Flu. Pro., pp. 53-73.

Curtis J B 2002 Fractured shale-gas systems; AAPG Bull. 86 1921-1938.

Dalai T K, Singh S K, Trivedi J R and Krishnaswami S 2002 Dissolved rhenium in the Yamuna River System and the Ganga in the Himalaya: Role of black shale weathering on the budgets of Re, Os, and $\mathrm{U}$ in rivers and $\mathrm{CO}_{2}$ in the atmosphere; Geochim. Cosmochim. Acta 66 29-43.

Dong D Z, Cheng K M, Wang S Q and Lu Z G 2009 An evaluation method of shale gas resource and its application in the Sichuan basin; Nat. Gas India 29 33-39 (in Chinese with English abstract).

Fu X D, Qin J Z and Teng G E 2008 Evaluation on excellent marine hydrocarbon source layers in southeast area of the Sichuan basin - an example from well D-1; Petrol. Geo. Exp. 30 621-628 (in Chinese with English abstract).

Guizhou Provincial Geological Survey Bureau 1987 The Regional Geology of Guizhou province; Geological Publishing House, Beijing, pp. 1-632 (in Chinese with English abstract).

Horan M F, Morgan J W, Grauch R I, Coverey Jr R M, Murowchick J B and Hulbert L J 1994 Rhenium and osmium isotopes in black shales and $\mathrm{Ni}-\mathrm{Mo}-\mathrm{PGE}-\mathrm{rich}$ sulfide layers, Yukon Territory, Canada, and Hunan and Guizhou province, China; Geochim. Cosmochim. Acta $\mathbf{5 8}$ 257-265.

Hou Y G, He S, Yi J Z, Zhang B Q, Chen X H, Wang Y, Zhang J K and Cheng C Y 2014 Effect of pore structure on methane sorption capacity of shales; Petrol. Geo. Exp. 41 248-256 (in Chinese with English abstract).

Huang J Z 2009 Exploration prospect of shale gas and coalbed methane in Sichuan Basin; Lith. Rev. 21 116-120 (in Chinese with English abstract).

Huang Y Z, Huang J L, Ge C M, Cheng K M and Dong D Z 2009 Prospects and strategic position of shale gas resources in China; Nat. Gas India 29 7-10 (in Chinese with English abstract).
Jaffe L A, Peucker-Ehrenbrink B and Petsch S T 2002 Mobility of rhenium, platinum group elements and organic carbon during black shale weathering; Earth Planet. Sci. Lett. 198 339-353.

Jia C Z, Zheng M and Zhang Y F 2012 Unconventional hydrocarbon resources in China and the prospect of exploration and development; Petrol. Explor. Dvpt. 39 129-136 (in Chinese with English abstract).

Jiang S Y, Chen Y Q, Ling $\mathrm{H} \mathrm{F}$, Yang J H, Feng $\mathrm{H} \mathrm{Z}$ and Ni P 2006 Trace and rare earth element geochemistry and $\mathrm{Pb}-\mathrm{Pb}$ dating of black shales and intercalated $\mathrm{Ni}-\mathrm{Mo}-\mathrm{PGE}-\mathrm{Au}$ sulfide ores in Lower Cambrian strata, Yangtze Platform, South China; Mineral. Deposits 41 453-467.

Li X J, Hu S Y and Cheng K M 2007 Suggestions from the development of fractured shale gas in North America; Petro. Explor. Dvpt. 34 392-400 (in Chinese with English abstract).

Li J, Yu B S, Xia X H, Tian Y K, Li Y L, Zhou H and Ma Y S 2014 The characteristics of the Upper Permian Shale Reservoir in the northwest of Guizhou Province, China; Earth Sci. Frontiers 21 1-11 (in Chinese with English abstract).

Littke R, Klussmann U, Krooss B and Leythaeuser D 1991 Quantification of loss of calcite, pyrite, and organicmatter due to weathering of Toarcian black shales and effects on kerogen and bitumen characteristics; Geochim. Cosmochim. Acta 55 3369-3378.

Liu S G, Wang H, Sun W, Dai H S and Qing C 2008 Analysis on special features of petroleum geological conditions of marine facies in Sichuan Basin; Oil. Gas Geol. 29 781-792 (in Chinese with English abstract).

Mao J W, Lehmann B, Du A D, Zhang G D, Ma D S, Wang Y T, Zeng M G and Kerrich R 2002 Re-Os dating of polymetallic $\mathrm{Ni}-\mathrm{Mo}-\mathrm{PGE}-\mathrm{Au}$ mineralization in lower Cambrian black shales of south China and its geologic significance; Econ. Geol. 97 1051-1061.

Mayer L M 1994 Relationships between mineral surfaces and organic carbon concentrations in soils and sediments; Chem. Geol. 114 347-363.

Nelson R A 1985 Geologic Analysis of Naturally Fractured Reservoirs: Contributions in Petroleum Geology and Engineering; Gulf Publishing Company, Houston, 320p.

Nesbitt H W and Young G M 1982 Early Proterozoic climates and plate motions inferred from major element chemistry of lutites; Nature 299 715-717.

Nesbitt H W and Young G M 1984 Prediction of some weathering trends of plutonic and volcanic rocks based on thermodynamic and kinetic considerations; Geochim. Cosmochim. Acta 48 1523-1534.

Nie H K, Zhang J C and Li Y X 2011 Accumulation conditions of the Lower Cambrian shale gas in the Sichuan Basin and its periphery; Acta. Petrol. Sin. 32 959-967 (in Chinese with English abstract).

Peng B, Song Z L, Tu X L, Lv H Z and Wu F C 2004 Release of heavy metals during weathering of the Lower Cambrian black shales in western Hunan, China; Environ. Geol. 45 1137-1147.

Peng B, Tang X Y, Yu C X, Xie S R, Xiao M L and Song Z 2009a Geochemistry of heavy metal contamination of the acid mine drainage from the Hejiacun uranium mine in central Hunan, China; Environ. Geol. 57 421-434.

Petsch S T, Berner R A and Eglinton T I 2000 A field study of the chemical weathering of ancient sedimentary organic matter; Org. Geochem. 31 475-487.

Petsch S T, Smernik R J, Eglinton T I and Oades J M 2001 A solid 13C-NMR study of kerogen degradation during black shale weathering; Geochim. Cosmochim. Acta $\mathbf{6 5}$ 1867-1882. 
Pittman E D 1992 Relationship of porosity and permeability to various parameters derived from mercury injectioncapillary pressure curves for sandstone; AAPG Bull. 76 191-198.

Qi L, Hu J and Gregoire D C 2000 Determination of trace elements in granites by inductively coupled plasma mass spectrometry; Talanta $\mathbf{5 1} 507-513$.

Ross D J K and Bustin R M 2008 Characterizing the shale gas resource potential of Devonian Mississippian strata in the western Canada sedimentary basin: Application of an integrated formation evaluation; AAPG Bull. 92 87-125.

Shang H Y, Li J C and Guo S L 1990 Organic geochemistry and fluorescence microscopy; Petroleum Industry Press, Beijing, pp. 12-25 (in Chinese).

Suess E 1973 Interaction of organic compounds with calcium carbonate-II: Organo-carbonate association in recent sediments; Geochim. Cosmochim. Acta 37 2435-2447.

Tang X, Zhang J C, Wang X Z, Yu B S, Ding W L, Xiong J Y, Yang Y T, Wang L and Yang C 2014 Shale characteristics in the southeastern Ordos Basin, China: Implications for hydrocarbon accumulation conditions and the potential of continental shales; Int. J. Coal Geol. 128 $32-46$.

Tanoue E and Handa N 1979 Differential sorption of organic matter by various sized sediment particles in recent sediment from the Bering Sea; J. Oceanogr. Soc. Japan 35 199-208.

Taylor S R and McLennan S M 1985 The Continental Crust: Its Composition and Evolution; Blackwell Scientific Publications, Oxford, 312p.

Tuttle M L W and Breit G N 2009 Weathering of the New Albany Shale, Kentucky, USA: I. Weathering zones defined by mineralogy and major-element composition; Appl. Geochem. 24 1549-1564.

Tuttle M L W, Breit G N and Goldhaber M B 2009 Weathering of the New Albany Shale, Kentucky: II. Redistribution of minor and trace elements; Appl. Geochem. 24 1565-1578.

Weiler R R and Mills A A 1965 Surface properties and pore structure of marine sediments; Deep-Sea. Res. 12 511-529.

Wen L, Hu S Y and Tian H Q 2001 A study on hydrocarbon source rock of Cambrian in Yangtze area, China; $N W$ Geol. 34 67-74 (in Chinese with English abstract).
Wildman R A, Berner R B, Petsch S T, Bolton E W, Eckert J O, Mok U and Evans J B 2004 The weathering of sedimentary organic matter as a control on atmospheric $\mathrm{O}_{2}$ : I. Analysis of black shale; Am. J. Sci. $304234-249$.

Wo Y Y, Zhou Y and Xiao K H 2007 The burial history and models for hydrocarbon generation and evolution in the marine strata in southern China; Sed. Geol. Tethyan Geol. 27 94-100 (in Chinese with English abstract).

Wu Y Q, Jin Z G and Cai X D 2012 Evaluation on resource potential and thoughts on exploitation of shale gas from Guizhou Province, China; Acta Mineral. Sin. 32 569-575 (in Chinese with English abstract).

Yan C Z, Huang Y Z, Ge C M, Dong D Z and Cheng K M 2009 Shale gas: Enormous potential of unconventional natural gas resources; Nat. Gas. India 29 1-6 (in Chinese with English abstract).

Ye L J 1996 Biological mineralization of organic matter; Maritime Press, Beijing, pp. 21-64 (in Chinese).

Yin H F 1999 Biological mineralization system theory; China University of Geosciences Press, Wuhan, pp. 1-35 (in Chinese).

Zeng W T, Zhang J C, Ding W L, Zhao S, Zhang Y Q, Liu Z J and Jiu K 2013 Fracture development in Paleozoic shale of Chongqing area (South China). Part one: Fracture characteristics and comparative analysis of main controlling factors; J. Asian Earth. Sci. 75 251-266.

Zhang J C, Xue H, Zhang D M and Pu J 2003 Shale gas and its reservoiring mechanism; Geoscience 17466 (in Chinese).

Zhang J C, Jin Z J and Yuan M S 2004 Reservoiring mechanism of shale gas and its distribution; Nat. Gas India $\mathbf{2 4}$ 15-18 (in Chinese with English abstract).

Zhang J C, Xu B, Nie H K and Deng F Y 2007 Two essential gas accumulations for natural gas exploration in China; Nat. Gas India 27 1-6 (in Chinese with English abstract).

Zhang J C, Jiang S L, Tang X, Zhang P X, Tang Y and Jin T Y 2009 Accumulation types and resources characteristics of shale gas in China; Nat. Gas India 29 1-6 (in Chinese with English abstract).

Zou C N, Dong D Z, Wang S J, Li J Z, Li X J, Wang Y M, Li D H and Cheng K M 2010 Geological characteristics, formation mechanism and resource potential of shale gas in China; Petro. Explor. Dvpt. 37 641-653 (in Chinese with English abstract). 